University of Rhode Island

DigitalCommons@URI

Open Access Master's Theses

2017

\title{
The Relationship Between Pre-Service Benchmarks and Student Teaching Performance
}

Alexis Carlson

University of Rhode Island, alexiscarlson@uri.edu

Follow this and additional works at: https://digitalcommons.uri.edu/theses

\section{Recommended Citation}

Carlson, Alexis, "The Relationship Between Pre-Service Benchmarks and Student Teaching Performance" (2017). Open Access Master's Theses. Paper 1019.

https://digitalcommons.uri.edu/theses/1019

This Thesis is brought to you for free and open access by DigitalCommons@URI. It has been accepted for inclusion in Open Access Master's Theses by an authorized administrator of DigitalCommons@URI. For more information, please contact digitalcommons-group@uri.edu. 


\section{THE RELATIONSHIP BETWEEN PRE-SERVICE BENCHMARKS AND STUDENT TEACHING PERFORMANCE}

BY ALEXIS CARLSON

A THESIS SUBMITTED IN PARTIAL FULFILLMENT OF THE REQUIREMENTS FOR THE DEGREE OF MASTER OF ARTS

IN EDUCATION 


\section{MASTER OF ARTS THESIS}

OF

\section{ALEXIS CARLSON}

\section{APPROVED:}

Thesis Committee:

Major Professor $\quad$ Diane Kern
Julie Coiro
Jay Fogleman
Stephen M. Barber
Nasser H. Zawia
DEAN OF THE GRADUATE SCHOOL

UNIVERSITY OF RHODE ISLAND

2017 


\begin{abstract}
From K-12 schools to higher education institutions, policy makers, parents, teachers, and other education stakeholders are concerned about the state of our nation's public schools. Issues of reform, accountability, retention, paths to licensure, and preparation of teachers populate education news and research. In the era of accountability, it is important for teacher preparation programs to look within themselves to ensure the structure and requirements of their program help prepare teacher candidates for student teaching and careers. While some insist on raising admission requirements, such as grade point averages (GPAs), others are concerned about the role of high stakes admission and licensure requirements in teacher preparation programs.

The focus of this thesis was to examine one Secondary English Language Arts teacher preparation program within a large, Research I institution in the northeast. A correlational study was conducted to determine the relationships between the various preservice benchmarks and candidates' student teaching performance. Regression models were used to determine if any of the pre-service benchmarks were predictors of other preservice benchmarks or predictors of student teaching performance.

Findings from this study reinforce existing literature on correlational relationships between pre-service benchmarks. Findings from the regression models add to the literature in the field. The results and implications of this study offer similar programs potential areas of reform.
\end{abstract}




\section{ACKNOWLEDGMENTS}

The idea, research, and preparation would not have been possible without the tremendous help and support from the University of Rhode Island's School of Education staff and faculty.

To Dr. Diane Kern, who has provided countless advising meetings both in her office and at her kitchen table for the last five years, thank you for your endless belief and support. You have inspired and encouraged me to pursue opportunities beyond my wildest expectations. Though this milestone is important, I think we can both agree it is not nearly as impressive as my technology-enhanced, social justice based, station activity during my first middle school observation.

To Dr. Julie Coiro, thank you for your thoughtful feedback during the proposal phase of this research. You challenged me to dive deeper into the research mindset and experience and laughed with me as I reminded you I was not nearly as "intense" as the Ph.D students with whom you normally work.

To Dr. Jay Fogleman, thank you for putting up with my mouth and trouble making tendencies for the past six years. I apologize for the gray hairs I may have caused. I appreciate the countless time we have spent dreaming and planning for the schools and students of the future. Thank you for convincing Mrs. Fogleman to bring Emmy in so many times just so I could hug her fluffy head.

To Dr. Stephen M. Barber, whose influence and impact on every aspect of my life cannot be quantified or put into words. Thank you for sharing your heart and mind. I will continue to strive for agency in life. Above all, you have taught me to choose love. 
To the Office of Teacher Education, specifically Janet Deignan, Daniel Riley, and Dr. Diana Marshall for their help in inspiring the topic of this thesis and for their assistance in the data collection process. You are the nicest people I know. Janet, thank you for always telling me everything would be okay. Dr. Marshall, thank you for your patience and life talks. Dan, thank you for your friendship and endless bravery. I love you all.

To Dr. Shim, for your openness and patience during the proposal phase of this study. You always had your door open to me and my endless questions. Your passion for research and teaching is infectious. Thank you for sharing your knowledge and heart.

To Nicole, from being my TA back in EDC 312 to becoming friends, you have been with me through it all. You are a tremendous person with a heart full of love. Your generosity and intelligence are limitless. Without your guidance, expertise, and assistance, much of my college career and especially this thesis would not have been possible. Thank you for your help. Above all, thank you for your friendship.

To Marsha and Lisa, for their immeasurable kindness, support, and help with the paperwork of this process. You two always have the answers. Thank you for always saying good morning, which will make it even more difficult to say goodbye.

Lastly, to Tory, who continues to teach me what it means to be compassionate, empathetic, and supportive. I treasure you, your support, and our love. To borrow a quote from the internet, "even if my findings are not significant, you will always be significant to me." Thank you for taking a step into the truly unknown with me. 


\section{DEDICATION}

To my first teachers: Dad, Mom, Erik, and Kristen 


\section{TABLE OF CONTENTS}

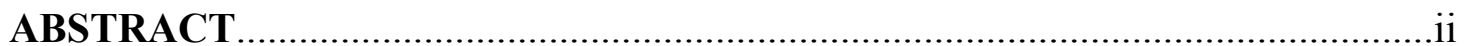

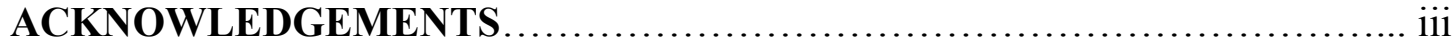

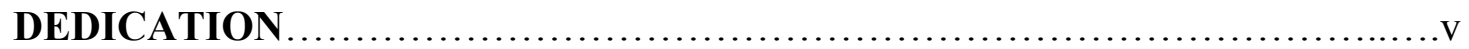

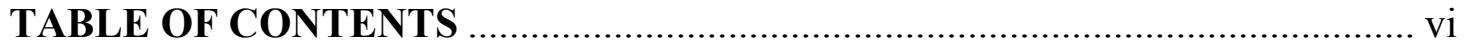

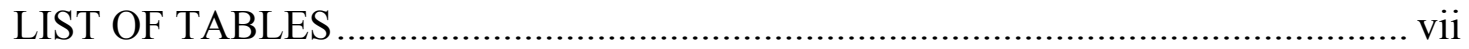

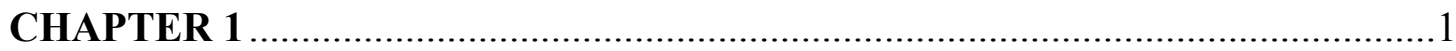

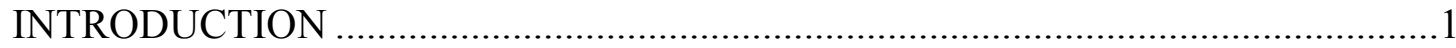

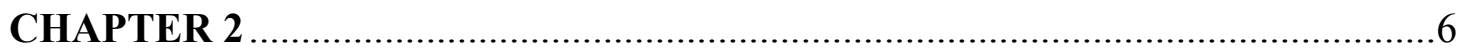

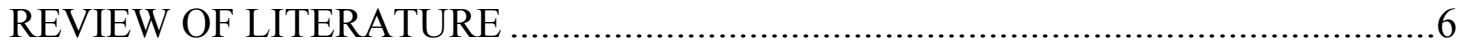

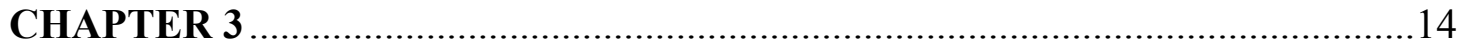

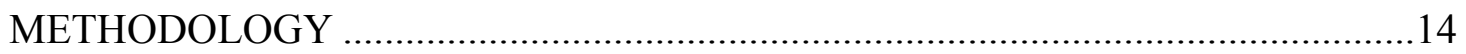

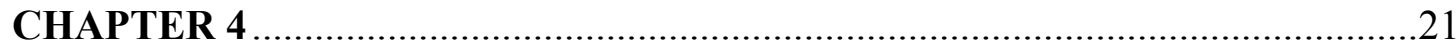

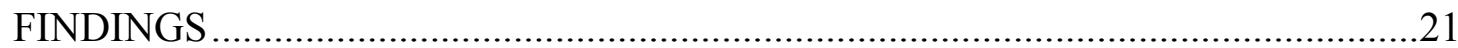

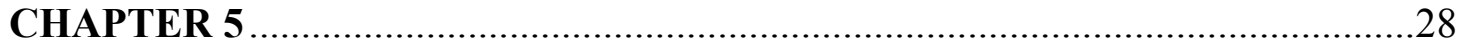

CONCLUSION

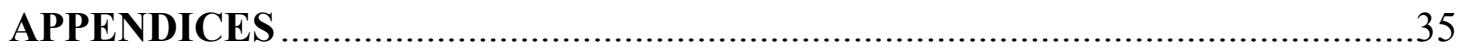

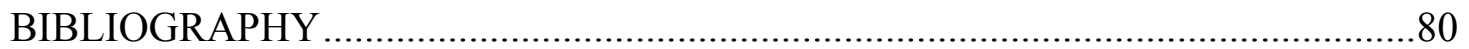




\section{LIST OF TABLES}

TABLE

PAGE

Table 1. Participants per Student Teaching Cohort. ................................................

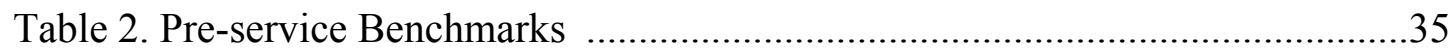

Table 3. Variables Entered/Removed ${ }^{a}$ with HS CT Evaluation as Dependent Variable

Table 4. Model Summary Enter Method with HS CT Evaluation as Dependent

Variable .61

Table 5. ANOVA Enter Method with HS CT Evaluation as Dependent Variable......62

Table 6. Coefficients ${ }^{a}$ Enter Method with HS CT Evaluation as Dependent

Variable

Table 7. Variables Enter/Removed ${ }^{a}$ Enter Method with MS CT Evaluation as

Dependent Variable .63

Table 8. Model Summary Enter Method with MS CT Evaluation as Dependent

Variable. .63

Table 9. ANOVA Enter Method with MS CT Evaluation as Dependent Variable......64

Table 10. Coefficients ${ }^{a}$ Enter Method with MS CT Evaluation as Dependent Variable.. .64

Table 11. Variables Enter/Removed ${ }^{a}$ Enter Method with US Evaluation as Dependent

Variable. .65

Table 12. Model Summary with US Evaluation as Dependent Variable. .65

Table 13. ANOVA Enter Method with US Evaluation as Dependent Variable. .66 
Table 14. Coefficients ${ }^{a}$ Enter Method with US Evaluation as Dependent

Variable.

.66

Table 15. Variables Entered/Removed ${ }^{a}$ Enter Method with Sum Score of Evaluations

as Dependent Variable.

Table 16. Model Summary Enter Method with Sum Score of Evaluations as

Dependent Variable.

Table 17. ANOVA Enter Method with Sum Score of Evaluations as Dependent

Variable.

Table 18. Coefficients ${ }^{a}$ Enter Method with Sum Score of Evaluations as Dependent

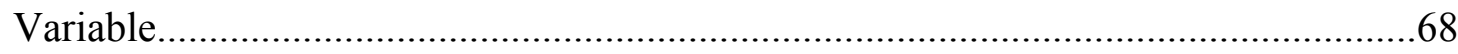

Table 19. Descriptive Statistics for Each Variable...................................................69

Table 20. Correlations between Pre-Service Benchmarks and Student Teaching

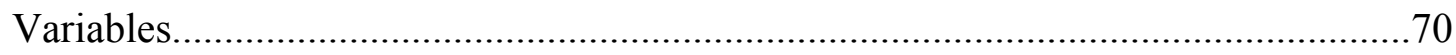

Table 21. Descriptive Statistics of Education Grade Point Averages and Principles of

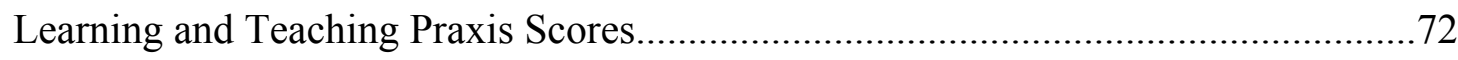

Table 22. Correlations between Education Grade Point Averages and Principles of

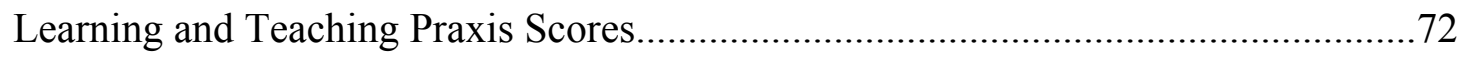

Table 23. Descriptive Statistics of English Grade Point Averages and English

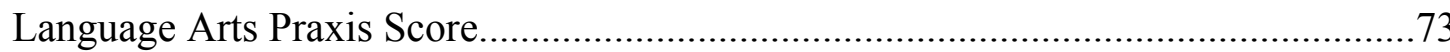

Table 24. Correlations between English Grade Point Averages and English Language

Arts Praxis Score. .73 
Table 25. Descriptive Statistics of Student Teaching Variables....................................74

Table 26. Correlations of Student Teaching Variables................................................74

Table 27. Correlations of Sum Score of Evaluations...................................................

Table 28. Variables Entered/Removed ${ }^{a}$ with PLT Praxis Score as Dependent

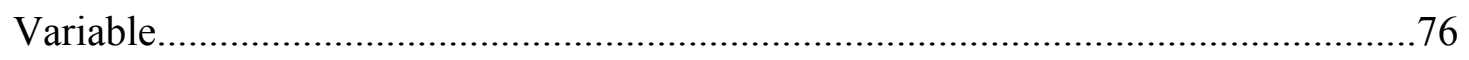

Table 29. Model Summary with PLT Praxis Score as Dependent Variable...................76

Table 30. ANOVA ${ }^{a}$ with PLT Praxis Score as Dependent Variable..............................76

Table 31. Coefficients ${ }^{a}$ with PLT Praxis Score as Dependent Variable.......................77

Table 32. Variables Entered/Removed ${ }^{a}$ with ENG Praxis Score as Dependent

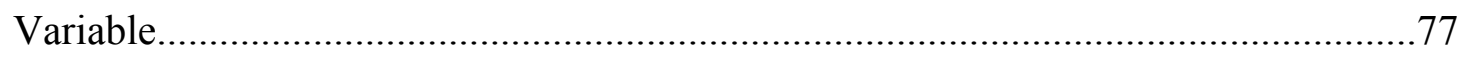

Table 33. Model Summary with ENG Praxis Score as Dependent Variable.................77

Table 34. ANOVA ${ }^{a}$ with ENG Praxis Score as Dependent Variable.............................78

Table 35. Coefficients ${ }^{a}$ with ENG Praxis Score as Dependent Variable........................78

Table 36. Descriptive Statistics Skewness of Variables................................................79 


\section{CHAPTER 1}

\section{INTRODUCTION}

Teacher preparation programs have been subject to skepticism and reform since their inception. There are growing concerns among parents, teachers, and policymakers about the quality of schools and the teachers within them (Ingersoll \& Collins, 2017; Klein, 2017). Policy makers are quick to conclude teacher preparation programs need to be reinvented to address these concerns (Hayes, 2002). The teacher retention problem contributes to these concerns. Riggs (2013) notes $9.5 \%$ of teachers will leave the field before the end of their first year. Broadening the scope, Ingersoll (2012) adds $40 \%$ and $50 \%$ of teachers leave the classroom within the first five years of their career. The large percentage of teachers leaving the field directly relates to the concerns about the quality of schools and teachers in them. In a school with a high turnover rate, administrators are stuck in a revolving cycle of continuously searching for new teachers (Zhang \& Zeller, 2016).

A report from the National Council for Accreditation of Teacher Education (NCATE) notes the solution to address these concerns is to "reform teaching so that more who enter will stay in the school building rather than be propelled back out the revolving door" (Wise, 2005, p. 2). These reports indicate an interest in reforming education to allow more invested teacher candidates into the field. Ironically, the solution many departments of education at the state and national level call for is to raise the standards candidates must meet in order to be admitted into a teacher 
preparation program or receive licensure, thus eliminating a wide range of potential teacher candidates. This phenomenon is part of a growing focus on accountability and reform efforts to improve the processes for admitting teacher candidates into teacher preparation programs (Jamil, Sabol, Hamre, \& Pianta, 2015).

Researchers and college faculty are rightfully concerned about the role of highstakes admission and licensure in undergraduate education (Moser, 2014; Petchauer, 2012; Thomas \& Loadman, 2001; Warren \& Curley, 1998; Watras, 2006). As a result of these concerns, educational institutions are interested in the level of preparedness, effectiveness, and quality of teacher candidates (Williams \& Alawiye, 2001). From the initial requirements for admittance into a teacher preparation program to the final licensure testing requirements and successful completion of student teaching, some education policymakers insist higher test scores for teacher candidates will produce high quality teachers. The higher cut scores on tests impact education majors immediately since the initial requirements for admittance into a teacher preparation program are often the first to rise.

In this era of accountability, it is essential for policy makers, university faculty, and other stakeholders to reexamine teacher education programs. Those concerned with educational accountability and reform must understand what aspects of teacher education programs lead to the development of successful student teachers who, after completing their program, enter the teaching workforce highly qualified (Leathwood $\&$ Phillips, 2000). Therefore, it is important for teacher preparation programs to look within themselves to better understand the needs of their teacher candidates (Kornfeld, Marker, Rudel, 2003). By doing so, teacher preparation programs can understand the 
relationship between aspects of their own program and the development of highly qualified teachers.

Current concerns about teacher education and the researcher's experiences as an undergraduate teacher candidate inspired the concept of this study. Throughout this thesis, independent variables are referred to as "pre-service benchmarks." This title was chosen because it accurately captures both the timeline and nature of the assessments I used in this study.

This study explores the relationship between pre-service teacher benchmarks and student teaching performance. The purpose of this study is twofold. First, the purpose is to determine if there is a relationship between the various requirements undergraduate education majors must meet. Second, this study aims to determine if the various requirements are predictive of effective student teaching performance. The results of this study will be shared with the School of Education faculty and administrators so they may be better able to determine which variables indicate greater student teaching success, which will inform teacher candidate advising and program revision.

\section{Limitations}

There are several limitations to this study the researcher recognizes. First, the convenience sampling from only one institution in the state and country is not necessarily generalizable. The researcher will attempt to address this concern by comparing data points to national averages, when possible. Another limitation of the study is the exclusion of other content areas (e.g. History/Social Studies, Mathematics, Sciences). The students of other disciplines have different cut scores for their Praxis 
content tests. Thus, the findings of this study may not be applicable to students of other content areas. Addressing such a concern is beyond the scope of this study, but future research should investigate pre-service benchmarks and successful student teaching for other content areas. Though a few issues around reform are mentioned in the introduction, this research only looks at the preparation of teacher candidates. Further research should include: qualitative information addressing how educational stakeholders would reform programs, a longitudinal study about the effectiveness of a program's student teachers throughout their career, the number of teacher program graduates who remain in the field after three, five, and seven years, and the relationship of pre-service benchmarks and teacher performance in non-traditional or alternative teacher licensure program.

\section{Significance}

The main audience for this research will be faculty teaching in English teacher education programs, although this study may also be of interest to additional groups, such as the university, the School of Education, faculty and staff within the program, teacher education candidates, curriculum reformers, and even policy makers. Due to the clinical nature of the teacher education program in this study, the results may impact public schools in the state, where teacher candidates complete pre-professional field experiences and student teaching. Should the results of this study find relationships between pre-service benchmarks and student teaching performance, program faculty might revise the nature of the student teaching experience and relationship with local schools. If a relationship is found, teacher education programs might place more emphasis on field experiences, which would affect local public 
schools and their students. Further research would need to be done to determine the impact teacher candidates have on student achievement in public school

classrooms. If relationships are found, program faculty and policy makers might revise the structure of their program in order to better prepare teacher candidates to be successful student teachers or rethink the purpose of pre-service benchmarks which may be obstructing students from student teaching experiences.

A correlational study by Wilson and Robinson (2012) notes standardized test scores do not relate to success in teaching and are thus unreliable in helping identify low-performing candidates. If the results of this study indicate there is no relationship between the pre-service benchmarks and successful student teaching, the results may be important at both the program and state level regarding admission and licensure. Such findings would add to the existing field of research regarding teacher candidate programs and their components. Further, findings might inspire teacher candidate programs to reflect on the value of some pre-service benchmarks in preparing teacher candidates for successful student teaching.

If there is a relationship between one or more of the variables considered to be a pre-service benchmarks and successful student teaching, the results may be important for professors within the program to understand about how to better serve their teacher candidates. 


\section{CHAPTER 2}

\section{REVIEW OF LITERATURE}

The expectations teacher candidates must meet during their programs have a strong research history. Many aspects of student teaching have been researched as well. Literature relevant to the pre-service benchmarks under analysis and student teaching performance mentioned below informed and inspired this thesis.

Pre-Service Benchmarks

Efforts to increase teacher quality and preparedness have focused on increasing admission and graduation standards for students in teacher preparation programs (Hall \& West, 2011). The pressure to raise standards for teacher candidates impacts education majors from the start of their undergraduate study. The position of these exams establishes the education major as "fundamentally different from others because students must test into it" (Petchauer, 2012, p. 252). Though the use of admission tests is unique to education majors, the use of high-stakes standardized testing to determine admittance and even graduation is not. It is common for many majors and programs (e.g., medical school, pharmacy, nursing) to use grade point averages as a way to ensure the quality of their students. Some policymakers and educational program administrators believe a passing score on a content area test, such as English or mathematics, is enough to be a qualified and effective teacher (Goldhaber, 2007). 
A review of 123 studies by D'Agostino and Powers (2009) indicates standardized test scores did not strongly relate to teaching performance. Two prior studies (Ferguson \& Womack, 1993; Guyton \& Farokhi, 1987) note education coursework to be a better predictor of teaching success than other benchmarks such as content area coursework and overall GPAs. In an era of teaching influenced by continued efforts to raise standards and high-stakes assessments, it is appropriate to question the evidence supporting these changes and review the literature surrounding this issue (Wilson \& Robinson, 2012).

A report from Ferguson and Womack (1993) offers an overview of the pressure teacher preparation programs face. In the 1980s, the debate between subject matter and education coursework was strengthened when academic and political interest groups united to "secure the adaptation of accreditation standards and legislative mandates prescribing increased content preparation at the expense of education coursework" (p. 55). Reform documents such as A Nation at Risk (1983) echoed these concerns. While there is little evidence to defend the idea of placing more importance on subject matter preparation to increase teacher performance, research and reports show evidence that education coursework has a positive effect on teaching performance (Ashton \& Crocker, 1987; Darling-Hammond, 1991; Everston, Hawley, \& Zlotnik, 1985; Ferguson \& Womack, 1993, p. 55). Ferguson and Womack (1993) found education coursework, of the variables they measured, to be the strongest predictor of teaching performance. Conversely, they found a teacher candidate's subject area grade point average was not a significant predictor of teaching performance (p. 60). Ferguson and Womack (1993) call for an assessment of existing 
evidence on the effect of education and subject matter coursework on "teaching performance and student learning and further research on the subject" (p. 55). This study answers that call and adds to the field of literature on this subject.

A summary report from Wilson, Floden, and Ferrini-Mundy (2001) notes prior research has explored the relative importance of pre-service benchmarks in regard to teacher preparation, and further research needs to be done to explore the "relationship between components of pedagogical preparation and teacher effectiveness" (p. 17). Since then, researchers have begun to explore the relationship between different assessment measures teacher candidates must pass throughout their program. Whether admission scores, education or content area grade point averages (GPAs), Praxis scores, or student teaching outcomes, studies have found mixed results in relationships between variables. Casey and Childs (2011) note few international studies have examined the relationship of admission criteria to teacher candidate preparedness to teach at the end of their program. Their report calls for further research to determine if entering GPAs have predictive value for successful student teaching performance. This thesis may help fill the gap in the research.

Hall and West (2011) analyzed relationships between variables such as GPA, American College Testing (ACT) scores, and Praxis exam scores. Their analysis found GPA and Praxis scores correlated significantly and positively with student teaching performance scores (Hall \& West, 2011). A multiple regression model consisting of Praxis scores and GPA variables explained sixteen percent of the variance in participants' student teaching performance scores. Hall and West (2011) acknowledge these results can support the movement to raise standards in teacher education 
programs, they note the current model leaves eighty-five percent of variance in student teaching performance unexplained. Hall and West (2011) argue raising standards might not lead to more prepared teacher candidates. While these efforts have occurred in an attempt to better prepare teachers, there is little empirical evidence to support these efforts (Zumwalt \& Craig, 2005).

Previous studies have found relationships between program requirements and student teaching performance, but with contradicting results. Guyton and Farokhi (1987) found GPA at the sophomore (typically the second year of college for a traditional undergraduate student) and upper level (usually checked prior to student teaching) were significantly correlated with teaching success. The researchers also found sophomore and upper level GPAs correlated significantly with teacher certification test scores and subject matter knowledge tests. However, their study showed subject matter test (like the Praxis II content test) scores were not correlated with teacher performance. Ferguson and Womack (1993) found education coursework accounted for $48 \%$ of the variance in teaching performance. Additionally, research found academic criteria including GPA and ACT scores failed to predict future student teacher performance (Byrnes, Kiger, \& Shechtman, 2003).

Furthermore, the Praxis series of tests, developed by Educational Testing Service (ETS), is one of the most widely used certification tests in the country. The Praxis I Core tests, which assess basic skills in reading, writing, and mathematics, are often used by teacher preparation programs as an admission requirement. After a few years in the program, teacher candidates must then pass the more advanced content knowledge and pedagogical knowledge tests. In programs like the one used in this 
study, teacher candidates must meet certain cut scores in order to advance in their program. These cut scores are determined by policymakers in each state. Often, they raise these cut scores in an attempt to strengthen the quality of their teachers. Schuls and Trivitt (2015) argue these policies operate under the assumption that a teacher candidate who "fails the exam by one question is not fit to teach, while the individual who earns a score equal to the cut score is deserving of a teaching certificate" (p. 653). However, evidence from Goldhaber (2007) contradicts this belief. In a study, Goldhaber (2007) found the state of North Carolina would lose more effective teachers if they raised their cut scores to match Connecticut's. Surprisingly, he found no improvement in the quality of North Carolina's teachers after increasing the cut score. Shuls and Trivitt (2015) point out that though the cut scores are determined by states to "weed out lower performing individuals" such scores provide "little information to future employers on the ability of prospective teachers" (p. 653). Yet, of all the collectable data, teacher licensure exam scores are among the most cited as having a positive relationship with teacher effectiveness" (p. 653-654). Though this study does not include Praxis I or other admission test scores, this study does use the subject Praxis II test scores as well as the pedagogical knowledge test scores for teacher candidates. Further research should include the use of admission test scores to determine the relationship between those scores and student teaching performance. Much like this English subject-specific study, Clotfelter, Ladd, and Vigdor (2010) conducted a study and found math subject test scores are significantly and positively correlated with teacher performance. While it is beyond the scope of this study to gather data from the students of the program's student teachers, it is important 
to note that Clotfelter et al. (2010) found licensure exams for English teachers had a significant negative relationship with student achievement in English. Further research should continue to explore the relationships across subject specific teacher programs. Student Teaching Performance

Studies show both veteran and new teachers consider clinical experiences in classrooms as a key component of teacher preparation (Wilson et al, 2001). Experiences while enrolled in a traditional teacher preparation program help develop teacher candidates prior to and during student teaching. A report from DarlingHammond, Chung, \& Frelow, 2002) indicates experiences help prepare teacher candidates to teach their content area, develop curriculum, and handle classroom management.

Cooperating teachers, teacher candidates, and university supervisors all play a role in the development of effective teachers. There is ample research exploring the influence of teacher education programs on the development of their teacher candidates. Adams and Krockover (1997) found beginning teachers attribute their knowledge of student-centered instruction, general pedagogical knowledge, and pedagogical content knowledge to their teacher education program. Furthermore, courses in teacher education provided candidates with a framework with which to organize, understand, and reflect on their experiences in classrooms. Such reflection contributes to the development of successful teachers while in their program and after. Grossman and Richert (1988) found prospective teachers cite education coursework and fieldwork as influential elements of their teacher preparation program, noting fieldwork as an aide in the development of their teaching practices. 
Existing research on clinical experiences provides an understanding of the qualities of effective teachers (Darling-Hammond, 2006; Darling-Hammond, 2010; Wilson et al, 2001; Scheerens \& Blömeke, 2016). Various studies provide findings regarding teacher preparation program assessment and teacher candidate effectiveness (Barnes, 2006; Boe, Shin, \& Cook, 2007; DiObilda, Bolay, \& Foster, 1990; Hayes, 2002; Morin 1996; Moser 2014; Pettus \& Smith, 1991; Thomas \& Loadman, 2001). The development of effective teachers is a central goal of a teacher preparation program. These above reports provide research regarding the qualities and dispositions of effective teachers.

Existing studies regarding student teacher perceptions of teacher training programs and student teaching experiences provide insight into teacher candidates' opinions and beliefs about their development over the course of the program (Hayes, 2002; Morin, 1996; Pettus and Smith, 1991; Thomas \& Loadman, 2001; William \& Alewife, 2001). However, little research was found that analyzed existing data from cooperating teachers in the context of program and teacher candidate evaluation and with the goal of determining the qualities of effective teacher candidates. By understanding how teacher candidates are evaluated in schools by their cooperating teachers and university supervisors, teacher preparation programs can develop a sense of how their student teachers perform. These evaluations can offer critical insight from cooperating teachers or university supervisors to not only help a teacher candidate develop, but can be used to review the preparedness of teacher candidates in general, or in specific key areas of development such as classroom management. While such research would likely produce fascinating results, it is beyond the scope of this study. 
Further research should determine the qualities and characteristics current teachers believe effective students teachers possess.

One goal of this study is to determine which pre-service benchmarks predict student teaching performance, an area of exploration that will contribute and expand upon existing research.

The following research questions guide this study:

1. Is there a relationship between the following pre-service benchmarks: education course grade point averages, content area course grade point averages, Principles of Learning and Teaching (PLT) Praxis II scores, Praxis II subject exam scores, and effective student teaching performance?

2. To what extent do the above pre-service benchmarks predict student teaching performance?

Data analysis expands upon the existing research in this field and may provide implications for teacher preparation programs. 


\section{CHAPTER 3}

\section{METHODOLOGY}

Existing studies provided the inspiration and foundation for this methodology. Wilson and colleagues (2001) argue research reports should explicitly explore the relationship of "teacher knowledge, skill, and practice that are thought important for effective teaching" (p. 33). Existing research on pre-service benchmarks provided the foundation for the research design of this study (Wilson \& Robinson, 2012; Hall \& West, 2011; Sandholtz et al, 2015). In many ways, this research was inspired by a report by Ferguson and Womack (1993) which sought to determine the extent to which "education and subject matter coursework predict the teaching performance of student teachers" (p. 59). The study by Ferguson and Womack (1993) inspired the research questions regarding the relationships between pre-service benchmarks and student teaching and the predictability of those benchmarks on student teaching performance. If there is a relationship between one or more of the variables considered to be a pre-service benchmarks and successful student teaching, the results may be important for professors within the program to understand about how to better serve their teacher candidates.

\section{Setting}

This study was conducted on a dataset from the School of Education at a large, public, Research I institution in the Northeastern region of the United States. 


\section{Study Population}

The study population was 2013-2016 program completers from the Secondary English Language Arts program at this public university. A complete dataset was available for a total of fifty-three program completers. This was a purposive convenience sample. Purposeful sampling was used to identify only students in the Secondary Education and English major since other content area students (such as Mathematics or Social Studies/History) have different requirements for Praxis exams. Secondary Education and English majors were the target population for whom the results of this study may impact. Participants were selected by using Filemaker to run a query pulling only the sampling and data needed for this study (see Appendix A, Table 1). One limitation of this study was the use of a convenience sample. Further research should draw on a larger random sample of Secondary Education and English Language Arts teacher candidates.

Only data of students who successfully completed the program were used for this study since the independent variable under consideration was student teaching performance, which is required for program completion and for teaching licensure. Since the researcher had no contact with participants or the current cohort of student teachers, participants had minimal to no risk. To protect the anonymity and confidentiality of the participants, the researcher's major professor de-identified the data and generated pseudonyms before data were made available to the researcher. The total number of participants was fifty-three $(n=53)$.

In this area, the researcher had two concerns related to the confirmability of this study. It is important to note as a graduate of this program the researcher does have a 
relationship with some of the participants in the study, especially those in the 2015 cohort of which the researcher was a member. Another concern was the researcher's own information was included in the data collected. To address these concerns, a School of Education faculty member generated the queries and the researcher's major professor de-identified the data. These actions greatly reduced any potential risk to participants since their anonymity was protected.

\section{Procedure}

1. IRB approval: The proposal for this study was submitted to the University of Rhode Island Institutional Review Board and was approved. Since the study is limited to analysis of de-identified existing data, it was not necessary to complete the full IRB application. Rather, a Secondary Data Analysis Worksheet was submitted to the IRB and approved.

2. Data collection: A request to access the data was approved by the Director of the School of Education. Next, the researcher's major professor accessed data available to her and also requested a query from the School of Education Outcomes Assessment Office (data located in TaskStream) and the Office of Teacher Education (data located in Filemaker). The researcher's major professor de-identified the dataset and shared data in an Excel file format.

3. Dataset description: The quantitative data included eight variables. Six independent variables were collected regarding pre-service benchmarks, and three variables were collected and combined to create one sum score regarding student teaching, the dependent variable. The following six pre-service benchmarks functioned as independent variables: 1) grade point averages for 
English courses at the time of admission, 2) grade point averages for Education courses at the time of admission, 3) Principles of Learning and Teaching (PLT) Praxis II scores, 4) subject area Praxis II scores, 5) grade point averages for English courses prior to student teaching, 6) grade point averages for Education courses prior to student teaching (see Appendix A, Table 2). The quantitative data collected regarding student teaching performance (the dependent variable) includes a sum score of rubric scores collected from both cooperating teachers and university supervisors using a common rubric (see Appendix B). Student teachers are formally observed by their cooperating teachers three times during the student teaching semester and by their university supervisor for three times during the student teaching semester. Both cooperating teachers and university supervisors complete a final evaluation for each student teacher. The scores from the final evaluations completed by the cooperating teacher(s) and university supervisors were added together to create a sum score for student teaching performance.

4. Instruments: The grade point averages (GPA) used in this study for both Education and English courses are on a 4.0 scale. For Education GPAs at the time of admission, students typically have one to two education courses completed. Prior to student teaching, Education majors complete a minimum of eight courses which are reflected in their Education GPA prior to student teaching. Participants in this study were required to maintain a 2.5 GPA in their Education courses, content major courses, and overall GPA. Due to changing standards and mandates from state and national accrediting agencies, 
this requirement is changing to a minimum 2.75 GPA. English grade point averages at the time of admission typically reflect two to three completed courses. Prior to student teaching, most Secondary Education and English majors have completed their required thirty-six credits in English coursework.

The Principles of Learning and Teaching Praxis Exam (Grades 7-12) is comprised of seventy selected-response questions and four constructedresponse questions. The five subcategories of questions are: i) Students and Learners, ii) Instructional Process, iii) Assessment, iv) Professional Development, Leadership, and Community, v) Analysis of Instructional Scenarios. Scores are out of a possible 200 points (Educational Testing Service, 2017, p.5). The 2015-2016 Understanding Your Praxis score report showed there were 28,337 test takers in the United States with an average performance range between 167-183, a median score of 175, a standard error of measurement of 5.7, and standard error for scoring of 2.5 (Educational Testing Service, 2016, p. 6). The minimum required for certification in Rhode Island is 157 (Educational Testing Service, 2017, Rhode Island Test Requirements).

The English Language Arts Content Knowledge Exam is comprised of 130 selected-response questions and two constructed-response questions. The three subcategories of scores are: i) Reading, ii) Language Use and Vocabulary, and iii) Writing, Speaking, and Listening. Scores are out of a possible 200 points (Educational Testing Service, 2017, p. 5). The 2015-2016 Understanding Your Praxis score report showed there were 2,812 test takers 
with an average performance range between 167-181, a median score of 174, a standard error of measurement of 4.8, and a standard error of scoring of 2.3 (Educational Testing Service, 2016, p. 4). The minimum required score for certification in Rhode Island is 168 (Educational Testing Service, 2017, Rhode Island Test Requirements).

Student teaching evaluations are scored in multiple ways. Each candidate is observed by their cooperating teacher(s) and university supervisors three times each. For the purposes of this study, only the final evaluations from each evaluator was used. Each evaluator uses a common rubric to score student teachers out of a total of 145 points each. The questions evaluators answer on a one to five Likert scale (see Appendix B). For the analysis using student teaching as a sum score, teacher candidates who completed student teaching at the middle and high school level could earn a possible 435 points, including the university supervisor evaluation. For students who completed student teaching at a high school only, their high school cooperating teacher final evaluation was added to the university supervisor final evaluation for a possible total of 290 points.

\section{Data Analysis}

To analyze the quantitative data, the researcher used Statistical Package for Social Science (SPSS) software version 24 to run correlations and regression analysis. Correlational data analysis was conducted to determine relationships between the different independent variables (six pre-service benchmarks). Pearson $r$ correlation coefficients were calculated to determine the association among pre-service 
benchmarks and student teaching performance at the specific school level (i.e. high school and middle school). Correlational data analysis was conducted to determine relationships between the pre-service benchmarks and student teaching performance (as the sum score and as individual variables).

The researcher ran a series of regression models to determine the predictability of pre-service benchmarks and student teaching performance. The data were analyzed through Pearson $r$ correlation coefficients, descriptive and frequency statistics. Data were also analyzed through Enter method, forward, backward, and step-wise regression models. Data analysis occurred through LSD, Tukey HSD, Bonferroni, Tamhane, Dunnett T3, and Games-Howell procedures for multiple comparisons to test for significant differences between group means.

This analysis helped researcher understand the extent to which each independent variable predicts student teaching performance. Correlational analysis aided in the researcher's understanding of the relationships between pre-service benchmarks and student teaching performance. The results of this data analysis are discussed in the next chapter. Findings may be significant for teacher preparation programs. 


\section{CHAPTER 4}

\section{FINDINGS}

Various combinations of variables were analyzed using SPSS to answer the research questions. The first approach was to separate student teaching variables into three scores--high school cooperating teacher final evaluations, middle school cooperating teacher final evaluations--and university supervisor final evaluations. Though this method did not acknowledge student teaching performance as one variable, it offered insight into the more specific relationships between pre-service benchmarks and student teaching performance at the individual level.

The researcher must address variables used in this study are not normally distributed (see Appendix O) and have a high level of skewness. Highly skewed variables might make regression models inappropriate to interpret in any meaningful way. Given skewness, the findings are hypothetical patterns that might be indicative of different kinds of relationships.

\section{Is There a Relationship Between Pre-Service Benchmarks and Student Teaching}

\section{Performance?}

The data were input into SPSS to run a correlation model (Appendix I, Table 20) to determine if there were any relationships between pre-service benchmarks and student teaching performance, considered as three separate variables (high school cooperating teacher's final evaluation scores, middle school cooperating teacher's final evaluation scores, and university supervisor's final evaluation scores). 
Correlational analysis showed multiple significant relationships among the pre-service benchmarks. Descriptive statistics were run to provide further insight into the performance of this program's teacher candidates (see Appendix H, Table 19).

Frequency statistics were run to determine the number of participants per cohort (see Appendix A, Table 1).

Pre-Service Benchmarks

Education GPA at admission and English GPA at admission correlated $(r=$ $.486, p=.000)$. Education GPA at admission and Education GPA before student teaching correlated $(r=.520, p=.000)$. Education GPA at admission and English GPA before student teaching correlated $(r=.370, p=.006)$. Lastly, Education GPA at admission correlated $(r=.317, p=.021)$ with teacher candidates' highest English Praxis content score. Education GPA did not significantly correlate with any student teaching performance variables.

English GPA and Education GPA at admission correlated $(r=.486, p=.000)$. English GPA at admission and Education GPA prior to student teaching correlated $(r$ $=.520, p=.000)$. English GPA at admission significantly correlated with English GPA prior to student teaching $(r=.778, p=.000)$. English GPA at admission correlated with teacher candidates' highest PLT score $(r=.539, p=.000)$ and with teacher candidates highest English Praxis content score $(r=.583, p=.000)$.

Education GPA prior to student teaching correlated with both Education and English GPA at admission $(r=.520, p=.000)$. Education GPA prior to student teaching significantly correlated with English GPA prior to student teaching $(r=.683$, $p=.000$ ). Education GPA prior to student teaching correlated with teacher candidates' 
highest PLT score $(r=.362, p=.008)$. Lastly, Education GPA prior to student teaching correlated with teacher candidates' highest English Praxis content score $(r=$ $.362, p=.008)$.

Teacher candidates' highest Principles of Learning and Teaching (PLT) Praxis exam score correlated with Education GPA at admission $(r=.539, p=.000)$. Teacher candidates' highest PLT exam score correlated with Education GPA before student teaching $(r=.362, p=.008)$. Teacher candidates' highest PLT exam score correlated with English GPA prior to student teaching $(r=.584, p=.000)$. Teacher candidates' highest PLT exam score significantly correlated with highest English Praxis content score $(r=.625, p=.000)$.

Teacher candidates' highest English Praxis score correlated with Education GPA at admission $(r=.317, p=.021)$, English GPA at admission $(r=.583, p=.000)$, Education GPA prior to student teaching $(r=.362, p=.008)$, English GPA prior to student teaching $(r=.616, p=.000)$, and with PLT scores $(r=.625, p=.000)$.

Though Education GPA at admission and prior to student teaching had a significant relationship, Education GPA at admission did not have a strong relationship with PLT scores. However, Education GPA before student teaching did have a significant relationship with PLT scores (see Appendix J, Table 22).

English GPA at admission had a strong relationship with English GPA prior to student teaching and a significant relationship with English Praxis scores. English GPA prior to student teaching has a stronger relationship with English Praxis scores than English GPA at admission (see Appendix K, Table 24). 
High school cooperating teacher final evaluations had a strong relationship with middle school cooperating teacher final evaluations and university supervisor final evaluations. The strongest relationship was between high school and middle school cooperating teacher final evaluations (see Appendix L, Table 26). Correlational Analysis with Student Teaching Performance as Three Separate Variables

Correlational analysis revealed none of the pre-service benchmarks had a significant relationship with student teaching performance when considered as three separate variables (high school cooperating teacher final evaluation, middle school cooperating teacher final evaluation, and university supervisor final evaluation). However, significant relationships were found among the student teaching performance variables.

High school cooperating teacher final evaluations were correlated with middle school cooperating teacher final evaluations $(r=.443, p=.002)$ and with university supervisor final evaluations $(r=.391, p=.004)$.

Middle school cooperating teacher final evaluations were correlated with high school cooperating teacher final evaluations $(r=.443, p=.002)$ and with university supervisor final evaluations $(r=.417, p=.004)$.

University supervisor evaluations were correlated with high school cooperating teacher final evaluations $(r=.391, p=.004)$ and with middle school cooperating teacher final evaluations $(r=.417, p=.004)$.

Correlational Analysis with Student Teaching Performance as a Sum Score 
To determine if there were any relationships between pre-service benchmarks and student teaching performance as a sum score, a correlational analysis was run. Since the six pre-service benchmarks remained the same in this analysis, the significant correlations between them are reflected above. However, correlational analysis showed there were no significant relationships between pre-service benchmarks and student teaching performance as a sum score (see Appendix M, Table 27).

To What Extent do the Pre-Service Benchmarks Predict Student Teaching Performance?

A series of regression models were run to determine the predictability of preservice benchmarks and student teaching performance. The Enter Method was used to input all independent variables and then one dependent variable. The Enter Method was used multiple times to create a few different reports. First, the six pre-service benchmarks as the independent variables and high school cooperating teacher final evaluation as the dependent variable (see Appendix D, Table 4). Results showed preservice benchmarks accounted for two percent of the variance in student teaching performance at the high school level. Second, the six pre-service benchmarks were entered into the model as the independent variables and middle school cooperating teacher final evaluation as the dependent variable, when applicable since not ever teacher candidate completes the middle level student teaching experience (see Appendix E, Table 4). Results from this analysis found pre-service benchmarks accounted for fifteen percent of the variance in student teaching performance at the middle school level. Third, the six pre-service benchmarks were entered into the 
model as the independent variables and university supervisor final evaluation as the dependent variable (see Appendix F). Results from this analysis accounted for nine percent of the variance in student teaching performance as evaluated by university supervisors (see Appendix F, Table 5).

Enter Method was used with the six pre-service benchmarks as the independent variables and the sum score of the evaluations as the dependent variable (see Appendix G). The Enter Method models showed the pre-service benchmarks used in this study were not statistically significant predictors of student teaching performance. The results of this method accounted for eight percent of variance (see Appendix G, Table 16).

For this particular test, forward, stepwise, and backward regression models were also attempted. SPSS would not produce a model for forward regression because the results were not statistically significant. Similarly, SPSS would not produce a model using the stepwise method. The researcher also ran a backward regression, which did not produce a model to determine the predictability of pre-service benchmarks and student teaching performance.

Interestingly, when SPSS produced the backward regression model and removed English GPA before student teaching, the variance did not change at all. Furthermore, when SPSS removed variables there was no change in the r2 value. Stepwise selection method was attempted but SPSS did not produce a model.

Enter method was used to determine if Education GPA at admission and prior to student teaching were predictive of Principles of Learning and Teaching (PLT) Praxis exam scores. Results showed Education grade point averages accounted for 
thirteen percent of variance in PLT scores (see Appendix N, Table 29). The Education GPA at admission was not a significant predictor $(p=.968)$. However, Education GPA prior to student teaching was a significant predictor of PLT exam scores ( $p=$ .024) (see Appendix N, Table 31).

Enter method was used to determine if English GPA at admission and prior to student teaching were predictive of English content Praxis exam scores. Results showed English GPA accounted for forty percent of the variance in English content Praxis exam scores (see Appendix N, Table 33). The English GPA at admission was not a significant predictor $(p=.137)$ but the English GPA prior to student teaching was $(p=.021)($ see Appendix N, Table 35). 


\section{CHAPTER 5}

\section{CONCLUSION}

In the educational era of accountability, it is now more important than ever for teacher preparation programs to look within themselves to determine if the requirements students must meet are necessary to prepare for successful student teaching experiences and beyond. The expectations teacher candidates must meet in order to continue through their program should prepare them for successful student teaching. Efforts to increase teacher quality and preparedness have focused on increasing admission and graduation requirements for teacher candidates (Hall \& West, 2011, p.145). While outside pressure for raising standards continues, it is appropriate to turn the lens inward to teacher preparation programs. However, it is important to keep existing research in mind while reviewing programs. A study by Ferguson and Womack (1993) indicates teacher preparation program improvements "will not be achieved by raising requirements beyond the existing floor of quality point average (2.5 out of 4.0)" (p. 61). However, the Rhode Island Department of Education has raised GPA standards for undergraduate teacher preparation programs to 2.75 out of 4.0 and for graduate students a 3.0 out of 4.0 (RIDE, 2013).

This thesis was prepared to determine if there were relationships between preservice benchmarks and student teaching performance and if pre-service benchmarks were predictive of student teaching performance. 
Existing research shows mixed results in answering these research questions. A review of 123 studies by D'Agostino and Powers (2009) indicates standardized test scores did not strongly relate to teaching performance. Correlational analysis in this study found similar findings, as neither the PLT Praxis exam nor the English Language Arts Praxis exam had significant relationships with student teaching performance.

Ferguson and Womack (1993) and Guyton and Farokhi (1987) found education coursework to be a better predictor of teaching success than other benchmarks such as content area coursework and overall GPAs. Other research echoes the conclusion that education coursework has a positive effect on teaching performance (Ashton \& Crocker, 1987; Darling-Hammond, 1991; Evertson, Hawley, \& Zlotnik, 1985; Ferguson \& Womack, 1993, p. 55). Ferguson and Womack (1993) found education coursework, of the variables they measured, to be the strongest predictors of teaching performance. Whereas the subject area GPA was not a significant predictor of teaching performance (p.60). Similar variables were used in this study and did not produce significant results to add to these findings regarding pre-service benchmarks and student teaching performance.

Hall and West (2011) found GPA and Praxis scores correlated significantly and positively with student teaching performance scores. The results of this study add to their findings as correlational analysis found significant relationships between education GPAs at admission and English Language Arts (ELA) Praxis scores, English GPAs at admission and both the PLT and ELA Praxis scores. Further, correlational analysis found both Education and English GPAs prior to student 
teaching had significant relationships with the PLT and the ELA Praxis. While Hall and West's (2011) multiple regression model consisting of Praxis scores and GPA variables explained sixteen percent of the variance in participants' student teaching performance scores, this study found pre-service benchmarks explained eight percent of student teaching performance scores.

Though teacher licensure exam scores are among the most cited as having a positive relationship with teacher effectiveness, analysis in this study determined there were no significant relationships between licensure exams and student teaching performance. However, regression analysis did find Education GPAs prior to student teaching were significant predictors of PLT scores and accounted for thirteen percent of the variance in PLT scores $(p=.024)$. Regression analysis also found English GPAs prior to student teaching were significant predictors of English Language Arts content exam scores and accounted for forty percent of variance on the Praxis exam $(p=$ .021). These findings are logical since Education courses and English courses are designed to prepare students for their licensure exams.

Interestingly, admission GPAs in both Education and English were not significant predictors of later licensure exam scores. Therefore, the role of admission GPAs as gatekeepers preventing students from entering the major should be reconsidered by teacher preparation programs. These findings are consistent with research from Henry et al. (2013) who noted "new and better indicators of candidates' strengths on entry and performance during the program will be needed to guide reform and continuous improvement of teacher preparation programs" (p. 440). Further, these test and GPA requirements may be contributing to the lack of diverse teaching candidates since Lee 
(2002) has conducted research on racial, ethnic, and economic gaps in test performance and has shown that with the exception of Asian students, students of color and students in low socioeconomic households score worse on these tests than their White and economically advantaged peers.

Interestingly, this study found there was a stronger relationship between English GPA at admission and PLT scores $(r=.539, p=.000)$ than Education GPA at admission and PLT scores $(r=.193, p=.166)$. The strongest correlational relationship this study found was between English GPA the time of admission and English GPA before student teaching $(r=.778, p=.000)$. These findings contradict the researcher's hypothesis that there would be a stronger relationship between Education grade point averages and the Principles of Learning and Teaching Exam since the PLT exam assess students' knowledge of educational theories, practices, etc.

The results of this study indicate the pre-service benchmarks collected at strategic points throughout the program are not significant predictors of student teaching performance. While significant relationships were found between the various preservice benchmarks, there were no significant relationships between any pre-service benchmark and student teaching performance. While significant correlational relationships were found between student teaching performance as evaluated by the high school cooperating teacher, middle school cooperating teacher, and university supervisor, these student teaching performance variables had no significant relationship with any of the pre-service benchmarks. Henry et al. (2013) note current indicators of progress and performance do not predict later effectiveness. Thus, "new and better indicators of candidates' strengths on entry and performance during the 
program will be needed to guide reform and continuous improvement" of teacher preparation programs (p. 440).

The development of successful teachers is a central goal of a teacher preparation program. Looking within at student teaching performance is one way to help determine if programs are developing successful teachers. Grossman and Richert (1988) found prospective teachers cite education coursework and fieldwork as influential elements of their teacher preparation program. By understanding how teacher candidates are evaluated in schools by their cooperating teachers and university supervisors, teacher preparation programs can develop a sense of how their student teachers perform. These evaluations can offer critical insight from cooperating teachers or university supervisors can be used to review the preparedness of teacher candidates in general, or in specific key areas of development such as classroom management.

Research from Shulman $(1986,1987)$ on content-specific pedagogical knowledge and research from (Mishra \& Koehler, 2006) on technological pedagogical content knowledge have been incorporated into the necessary skills student teachers must possess. The teacher preparation program in this study does not currently have an assessment for content-specific pedagogical knowledge or technological pedagogical content knowledge. Teacher preparation programs should consider the use of assessments on these areas to help ensure their teacher candidates are developed and able to perform. Correlational analysis in this study found significant relationships between teacher candidates' performance as evaluated by their high school cooperating teacher, middle school cooperating teacher, and university supervisor. 
Further research may provide valuable information for teacher preparation programs in this area.

Measures of professional dispositions, or the collections of behaviors, attitudes, and teaching qualities have been seen as critical components of teacher preparation programs (Flowers, 2006). Currently, the Council for the Accreditation of Educator Preparation, (CAEP, 2013) requires teacher preparation programs to assess their candidates' content knowledge, pedagogical content knowledge, and pedagogical skills as well as professional knowledge, skills, and dispositions necessary to "advance the learning of all students" (p.1). Future research should determine if a valid and reliable dispositions assessment could be a significant predictor of student teaching performance.

Flexible program changes in these requirements may bring more passionate, capable, and diverse teacher candidates into the field. The findings may inspire teacher candidate programs to reflect on the value of some pre-service benchmarks in preparing teacher candidates for student teaching. Further research should determine if dispositions assessments are significant predictors of student teaching performance. Future research should expand upon this study to include participants from other institutions to have a more representative sample. Research should interview current teachers, teacher candidates, and administrators to determine the essential knowledge, skills, and dispositions required for successful teaching performance.

\section{Limitations}

The researcher recognizes there are several limitations to this study. First, the convenience sampling from only one institution in the state and country is not 
necessarily generalizable. The researcher attempted to address this concern by comparing data points to national averages, when possible. Another limitation of the study was the exclusion of other content areas (e.g. History/Social Studies, Mathematics, Sciences). The students of other disciplines have different cut scores for their Praxis content tests. Thus, the findings of this study may not be applicable to students of other content areas. Addressing such a concern was beyond the scope of this study, but future research should investigate pre-service benchmarks and successful student teaching for other content areas.

Highly skewed variables might make regression models inappropriate to interpret in any meaningful way. Readers should take caution in using the results of this study to guide reform. The student teaching evaluation rubrics may not be valid assessments since evaluators commonly rate students between three and five since giving a student a one or two pulls them from student teaching.

Further research should include: qualitative information addressing how educational stakeholders would reform programs, a longitudinal study about the effectiveness of a program's student teachers throughout their career, the number of teacher program graduates who remain in the field after three, five, and seven years, and the relationship of pre-service benchmarks and teacher performance in nontraditional or alternative teacher licensure program. Also, further research should explore the use of dispositions assessments in teacher preparation programs. Further research should also explore the use of content pedagogical knowledge assessments and technological content pedagogical knowledge in teacher preparation programs. 


\section{APPENDICES}

Appendix $A$

Table 1: Participants per Student Teaching Cohort

\begin{tabular}{|l|l|}
\hline Student Teaching Cohort Year & $n$ \\
\hline 2013 & 15 \\
\hline 2014 & 12 \\
\hline 2015 & 15 \\
\hline 2016 & 11 \\
\hline & $N=53$ \\
\hline
\end{tabular}

Table 2: Pre-Service Benchmarks

\begin{tabular}{|l|l|l|}
\hline $\begin{array}{l}\text { Education courses GPA: } \\
\text { At time of admission into }\end{array}$ & English courses GPA & At time of admission into \\
School of Education & School of Education & Overall score can range \\
(typically 2 courses) & from 100-200 points \\
\hline $\begin{array}{l}\text { Education courses GPA: } \\
\text { Prior to student teaching }\end{array}$ & English courses GPA: & Prior to student teaching \\
semester (typically 8 & semester (typically & Scores: \\
courses) & completed 36 required & Overall score can range \\
from 100-200 points
\end{tabular}




\section{Appendix $B$}

This appendix includes a completed example of the common rubric evaluators use to score student teaching performance. Identifying information has been removed.

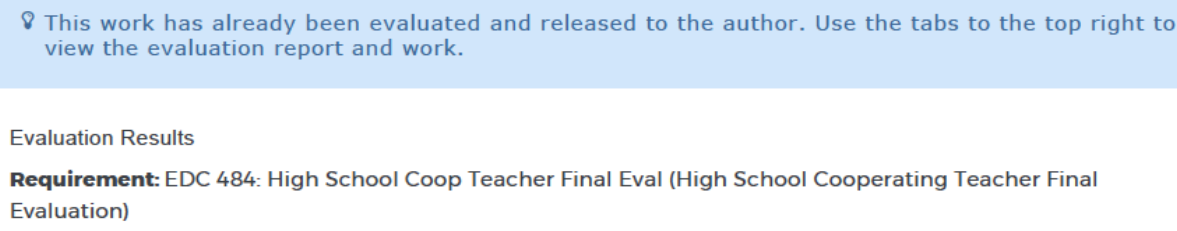

Detailed Results

(Rubric used: Cooperating Teacher Student Teaching Evaluation)

1.1 CONNECTING STUDENTS' PRIOR KNOWLEDGE, LIFE EXPERIENCE, AND INTERESTS WITH LEARNING GOALS

1. LITTLE

EVIDENCE

APPROACHING

THE

3. MEETS THE

STANDARD

STANDARD

Opens lesson

to capture

Asks

questions that activities and
4. ABOVE THE

STANDARD

Uses

questions and
5. WELL

ABOVE THE

STANDARD

Creates a

context for cleastod 5 taskstream 


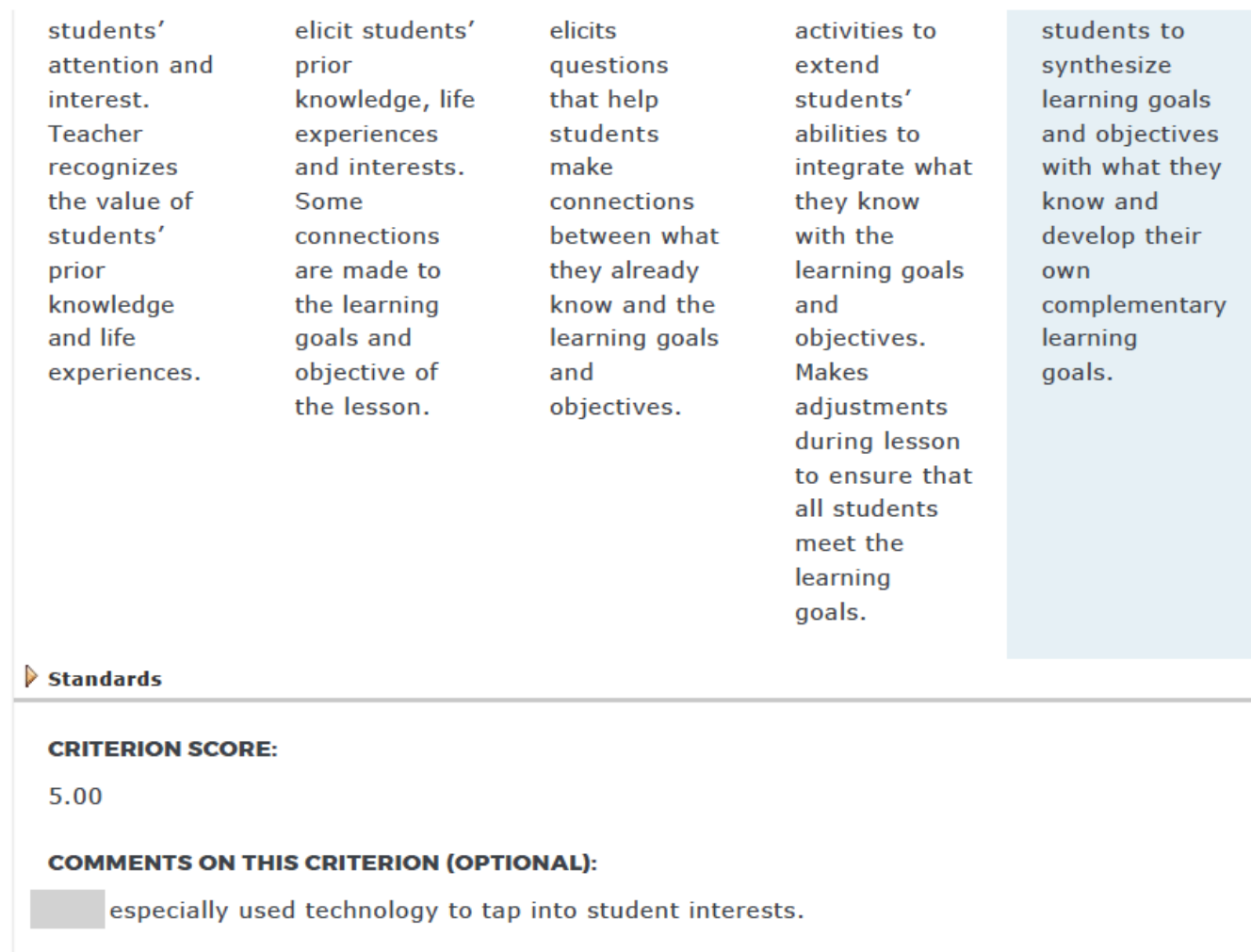

\subsection{USING A VARIETY OF INSTRUCTIONAL STRATEGIES AND RESOURCES TO RESPOND TO STUDENTS' DIVERSE NEEDS}

\section{LITTLE} EVIDENCE

Uses a few instructional strategies.

Delivers

instruction with available
2.

APPROACHING

THE

STANDARD

Varies
instruction to
increase
student
participation.
Selects

Varies to Selects

3. MEETS THE
STANDARD
Elicits student
participation
through a
variety of
instructional
strategies

4. ABOVE THE
STANDARD

Uses a repertoire of strategies and resources.

Select and differentiates
5. WELL ABOVE THE STANDARD

Uses extensive repertoire of strategies to meet students' 


\begin{tabular}{|c|c|c|c|c|}
\hline $\begin{array}{l}\text { resources } \\
\text { and } \\
\text { materials. }\end{array}$ & $\begin{array}{l}\text { strategies, } \\
\text { resources, and } \\
\text { visuals with } \\
\text { some } \\
\text { consideration } \\
\text { of students' } \\
\text { academic and } \\
\text { linguistic } \\
\text { needs. }\end{array}$ & $\begin{array}{l}\text { intended to } \\
\text { match } \\
\text { students' } \\
\text { academic and } \\
\text { linguistic } \\
\text { needs. Checks } \\
\text { for student } \\
\text { understanding. }\end{array}$ & $\begin{array}{l}\text { learning to } \\
\text { accommodate } \\
\text { students' } \\
\text { diverse } \\
\text { learning } \\
\text { styles. }\end{array}$ & $\begin{array}{l}\text { diverse } \\
\text { academic and } \\
\text { linguistic } \\
\text { needs and } \\
\text { ensure fullest } \\
\text { participation } \\
\text { and learning } \\
\text { for all } \\
\text { students. }\end{array}$ \\
\hline
\end{tabular}

CRITERION SCORE:

4.00

1.3 FACILITATING LEARNING EXPERIENCES THAT PROMOTE AUTONOMY, INTERACTION, AND CHOICE

\begin{tabular}{|c|c|c|c|c|}
\hline 1. LITTLE & 2. & 3. MEETS THE & 4. ABOVE THE & 5. WELL \\
\hline EVIDENCE & $\begin{array}{l}\text { APPROACHING } \\
\text { THE } \\
\text { STANDARD }\end{array}$ & STANDARD & STANDARD & $\begin{array}{l}\text { ABOVE THE } \\
\text { STANDARD }\end{array}$ \\
\hline $\begin{array}{l}\text { Directs } \\
\text { learning } \\
\text { experiences } \\
\text { through whole } \\
\text { group and } \\
\text { individual } \\
\text { work with } \\
\text { possibilities } \\
\text { for interaction } \\
\text { and choice. }\end{array}$ & $\begin{array}{l}\text { Varies learning } \\
\text { experiences to } \\
\text { include work in } \\
\text { large groups } \\
\text { and small } \\
\text { groups, with } \\
\text { student choice } \\
\text { within learning } \\
\text { activities. }\end{array}$ & $\begin{array}{l}\text { Provides } \\
\text { learning } \\
\text { experiences } \\
\text { utilizing } \\
\text { individual and } \\
\text { group } \\
\text { structures to } \\
\text { develop } \\
\text { autonomy and } \\
\text { group } \\
\text { participation } \\
\text { skills. } \\
\text { Students } \\
\text { make choices } \\
\text { about and } \\
\text { within their } \\
\text { work. }\end{array}$ & $\begin{array}{l}\text { Uses a variety } \\
\text { of learning } \\
\text { experiences to } \\
\text { assist } \\
\text { students in } \\
\text { developing } \\
\text { independent } \\
\text { working skills } \\
\text { and group } \\
\text { participation } \\
\text { skills. } \\
\text { Supports } \\
\text { student in } \\
\text { making } \\
\text { appropriate } \\
\text { choices for } \\
\text { learning. }\end{array}$ & $\begin{array}{l}\text { Integrates a } \\
\text { variety of } \\
\text { challenging } \\
\text { learning } \\
\text { experiences } \\
\text { that develop } \\
\text { students' } \\
\text { independent } \\
\text { learning, } \\
\text { collaboration, } \\
\text { and choice. }\end{array}$ \\
\hline
\end{tabular}




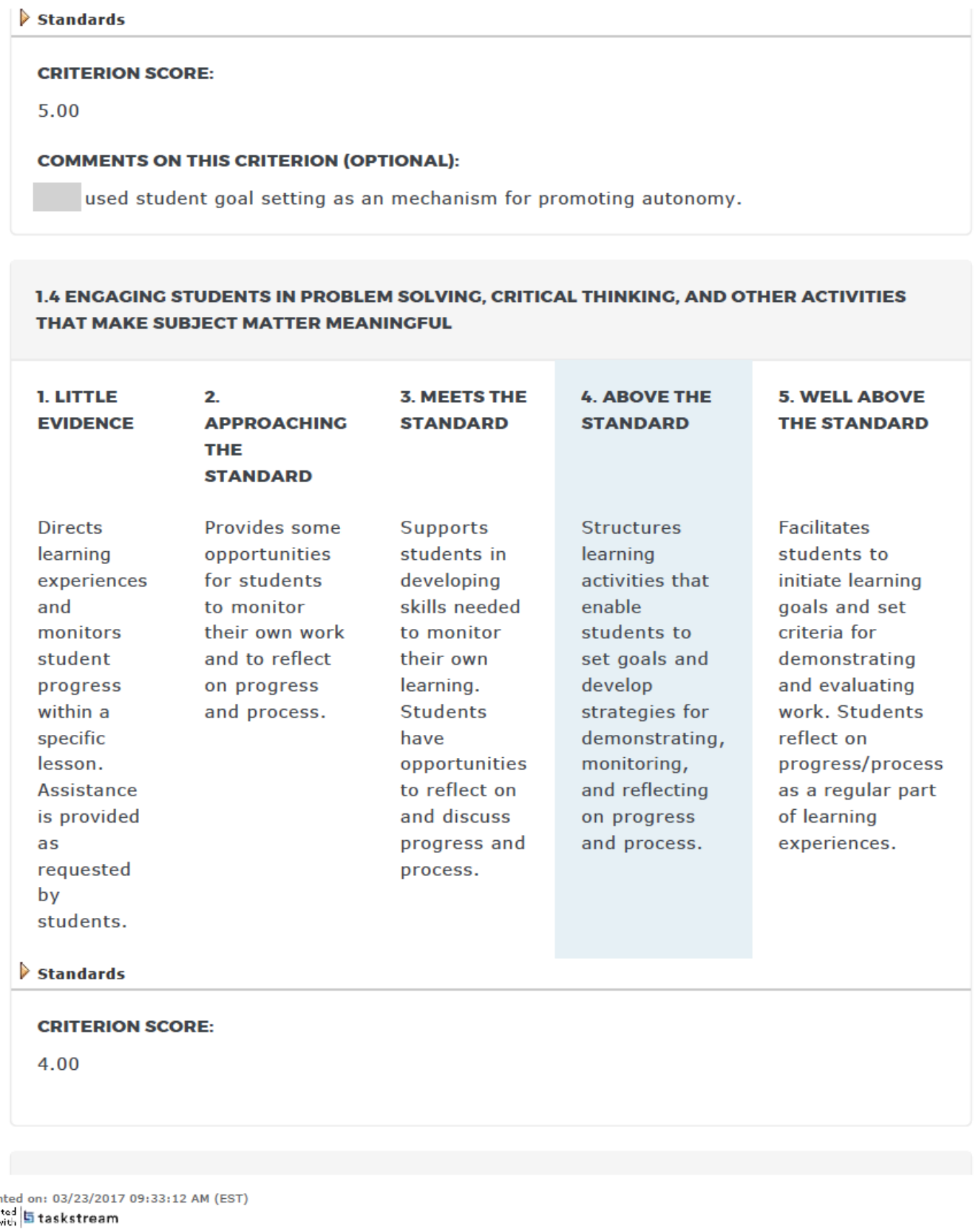




\subsection{CREATING A PHYSICAL ENVIRONMENT THAT ENGAGES ALL STUDENTS}

\begin{tabular}{|c|c|c|c|c|}
\hline $\begin{array}{l}\text { 1. LITTLE } \\
\text { EVIDENCE }\end{array}$ & $\begin{array}{l}2 . \\
\text { APPROACHING } \\
\text { THE } \\
\text { STANDARD }\end{array}$ & $\begin{array}{l}\text { 3. MEETS THE } \\
\text { STANDARD }\end{array}$ & $\begin{array}{l}\text { 4. ABOVE THE } \\
\text { STANDARD }\end{array}$ & $\begin{array}{l}\text { 5. WELL } \\
\text { ABOVE THE } \\
\text { STANDARD }\end{array}$ \\
\hline $\begin{array}{l}\text { Arranges } \\
\text { room for } \\
\text { teacher } \\
\text { accessibility to } \\
\text { or visibility of } \\
\text { students. } \\
\text { Room displays } \\
\text { relate to the } \\
\text { curriculum. } \\
\text { Movement and } \\
\text { access may be } \\
\text { restricted by } \\
\text { barriers. }\end{array}$ & $\begin{array}{l}\text { Arranges and } \\
\text { manages room } \\
\text { for easy } \\
\text { movement and } \\
\text { access to } \\
\text { resources. } \\
\text { Room displays } \\
\text { represent } \\
\text { current topics } \\
\text { of study. }\end{array}$ & $\begin{array}{l}\text { Designs } \\
\text { movement } \\
\text { patterns and } \\
\text { access to } \\
\text { resources to } \\
\text { promote } \\
\text { individual and } \\
\text { group } \\
\text { engagement. } \\
\text { Room displays } \\
\text { are used in } \\
\text { learning } \\
\text { activities. }\end{array}$ & $\begin{array}{l}\text { Designs and } \\
\text { manages } \\
\text { room and } \\
\text { resources to } \\
\text { accommodate } \\
\text { students' } \\
\text { needs and } \\
\text { involvement in } \\
\text { learning. } \\
\text { Displays are } \\
\text { integral to } \\
\text { learning } \\
\text { activities. }\end{array}$ & $\begin{array}{l}\text { Uses total } \\
\text { physical } \\
\text { environment } \\
\text { as a resource } \\
\text { to promote } \\
\text { individual and } \\
\text { group } \\
\text { learning. } \\
\text { Students are } \\
\text { able to } \\
\text { contribute to } \\
\text { the changing } \\
\text { design of the } \\
\text { environment. }\end{array}$ \\
\hline
\end{tabular}

CRITERION SCORE:

4.00

COMMENTS ON THIS CRITERION (OPTIONAL):

Often focused on and reflective of the classroom environment

2.2 ESTABLISHING A CLIMATE THAT PROMOTES FAIRNESS AND RESPECT

EVIDENCE

APPROACHING

THE

STANDARD

Establishes

rapport with

individual

students.

Printed on: 03/23/2017

cestod
witi
Builds caring, friendly most rapport with

\section{MEETS THE}

STANDARD

Promotes caring and

respectful

interactions.
4. ABOVE THE STANDARD

Maintains caring, respectful, and equitable
5. WELL ABOVE THE STANDARD

Fosters a safe, inclusive, and equitable learning 


\begin{tabular}{|c|c|c|c|c|}
\hline $\begin{array}{l}\text { Acknowledges } \\
\text { some } \\
\text { incidents of } \\
\text { unfairness } \\
\text { and } \\
\text { disrespect. }\end{array}$ & $\begin{array}{l}\text { students. } \\
\text { Models } \\
\text { equitable and } \\
\text { respectful } \\
\text { relationships. } \\
\text { Has some } \\
\text { strategies to } \\
\text { respond to } \\
\text { unfairness and } \\
\text { disrespect. }\end{array}$ & $\begin{array}{l}\text { Responds to } \\
\text { incidents of } \\
\text { unfairness } \\
\text { and disrespect } \\
\text { equitably. } \\
\text { Encourages } \\
\text { students to } \\
\text { respect } \\
\text { differences. }\end{array}$ & $\begin{array}{l}\text { relationships } \\
\text { with students. } \\
\text { Supports } \\
\text { students in } \\
\text { developing } \\
\text { skills to } \\
\text { respond to } \\
\text { inequity and } \\
\text { disrespect. }\end{array}$ & $\begin{array}{l}\text { community. } \\
\text { Students } \\
\text { participate in } \\
\text { maintaining a } \\
\text { climate of } \\
\text { equity, caring } \\
\text { and respect } \\
\text { and may } \\
\text { initiate } \\
\text { creative } \\
\text { solutions to } \\
\text { conflicts. }\end{array}$ \\
\hline \multicolumn{5}{|l|}{$\triangleright$ standards } \\
\hline \multicolumn{5}{|c|}{ CRITERION SCORE: } \\
\hline 5.00 & & & & \\
\hline
\end{tabular}

2.3 PROMOTING SOCIAL DEVELOPMENT AND GROUP RESPONSIBILITY

\section{LITTLE EVIDENCE}

Encourages student responsibility for self. Creates opportunities for individual students to have classroom responsibilities. APPROACHING THE STANDARD

Uses some strategies and activities to develop students' individual responsibility and recognition of others' rights and needs.

Students share in classroom responsibilities.

3. MEETS THE
STANDARD
Promotes
positive
student
interactions
as members
of large and
small groups.
Provides
some
opportunities
for student
leadership
within the
classroom.

4. ABOVE

THE

STANDARD

Engages students in individual and group work that promotes responsibility to the classroom community. Supports students to take initiative in classroom leadership.
5. WELL ABOVE THE STANDARD

Facilitates an environment in which students take initiative socially and academically. Promotes and supports student leadership beyond the classroom.

$D$ Standards

Printed on: 03/23/2017 09:33:12 AM (EST)

$\begin{gathered}\text { scostod } \\ \text { witi }\end{gathered} \mid$ taskstream 


\section{CRITERION SCORE:}

4.00

2.4 ESTABLISHING AND MAINTAINING STANDARDS FOR STUDENT BEHAVIOR

\begin{tabular}{|c|c|c|c|c|}
\hline 1. LITTLE & 2. & 3. MEETS THE & 4. ABOVE THE & 5. WELL \\
\hline EVIDENCE & $\begin{array}{l}\text { APPROACHING } \\
\text { THE } \\
\text { STANDARD }\end{array}$ & STANDARD & STANDARD & $\begin{array}{l}\text { ABOVE THE } \\
\text { STANDARD }\end{array}$ \\
\hline $\begin{array}{l}\text { Communicates } \\
\text { rules and } \\
\text { consequences. } \\
\text { Responds to } \\
\text { disruptive } \\
\text { behavior. } \\
\text { Focuses on } \\
\text { presenting } \\
\text { lessons. }\end{array}$ & $\begin{array}{l}\text { Establishes } \\
\text { expectations } \\
\text { and } \\
\text { consequences } \\
\text { for student } \\
\text { behavior. } \\
\text { Responds } \\
\text { appropriately } \\
\text { to disruptive } \\
\text { behavior and } \\
\text { promotes } \\
\text { some positive } \\
\text { behaviors. }\end{array}$ & $\begin{array}{l}\text { Uses } \\
\text { strategies } \\
\text { that prevent } \\
\text { or lessen } \\
\text { disruptive } \\
\text { behavior and } \\
\text { reinforce } \\
\text { expectations } \\
\text { for behavior. } \\
\text { Monitors } \\
\text { behavior while } \\
\text { teaching and } \\
\text { during } \\
\text { student work } \\
\text { time. }\end{array}$ & $\begin{array}{l}\text { Equitably } \\
\text { reinforces } \\
\text { expectations } \\
\text { and } \\
\text { consequences } \\
\text { and supports } \\
\text { students to } \\
\text { monitor their } \\
\text { own behavior } \\
\text { and each } \\
\text { other's in a } \\
\text { respectful } \\
\text { way. }\end{array}$ & $\begin{array}{l}\text { Facilitates a } \\
\text { positive } \\
\text { environment } \\
\text { in which } \\
\text { students are } \\
\text { guided to take } \\
\text { a strong role } \\
\text { in maintaining } \\
\text { and } \\
\text { monitoring } \\
\text { behavior. }\end{array}$ \\
\hline
\end{tabular}

CRITERION SCORE:

4.00

2.5 PLANNING AND IMPLEMENTING CLASSROOM PROCEDURES AND ROUTINES THAT SUPPORT STUDENT LEARNING

Printed on: 03/23/2017 09:33:12 AM (EST)

clested
witi t taskstream 


\begin{tabular}{|c|c|c|c|c|}
\hline $\begin{array}{l}\text { 1. LITTLE } \\
\text { EVIDENCE }\end{array}$ & $\begin{array}{l}2 . \\
\text { APPROACHING } \\
\text { THE } \\
\text { STANDARD }\end{array}$ & $\begin{array}{l}\text { 3. MEETS THE } \\
\text { STANDARD }\end{array}$ & $\begin{array}{l}\text { 4. ABOVE THE } \\
\text { STANDARD }\end{array}$ & $\begin{array}{l}\text { 5. WELL } \\
\text { ABOVE THE } \\
\text { STANDARD }\end{array}$ \\
\hline $\begin{array}{l}\text { Establishes } \\
\text { some } \\
\text { procedures to } \\
\text { support } \\
\text { student } \\
\text { learning. } \\
\text { Students are } \\
\text { aware of the } \\
\text { procedures. }\end{array}$ & $\begin{array}{l}\text { Develops and } \\
\text { guides } \\
\text { students to } \\
\text { learn routines } \\
\text { and } \\
\text { procedures for } \\
\text { most } \\
\text { activities. }\end{array}$ & $\begin{array}{l}\text { Identifies, } \\
\text { supports, and } \\
\text { monitors } \\
\text { students in } \\
\text { following } \\
\text { routines and } \\
\text { procedures } \\
\text { that are } \\
\text { appropriate } \\
\text { and efficient } \\
\text { for the } \\
\text { learning } \\
\text { activities. }\end{array}$ & $\begin{array}{l}\text { Uses } \\
\text { strategies to } \\
\text { assist } \\
\text { students in } \\
\text { developing } \\
\text { and } \\
\text { maintaining } \\
\text { equitable } \\
\text { routines and } \\
\text { procedures. }\end{array}$ & $\begin{array}{l}\text { Assists all } \\
\text { students in } \\
\text { developing } \\
\text { and } \\
\text { internalizing } \\
\text { equitable } \\
\text { routines and } \\
\text { procedures. } \\
\text { Students } \\
\text { show } \\
\text { ownership of } \\
\text { routines and } \\
\text { procedures. }\end{array}$ \\
\hline$\downarrow$ standards & & & & \\
\hline $\begin{array}{l}\text { CRITERION SC } \\
5.00\end{array}$ & & & & \\
\hline
\end{tabular}

\subsection{USING INSTRUCTIONAL TIME EFFECTIVELY}

$\begin{array}{ll}\begin{array}{l}\text { 1. LITTLE } \\ \text { EVIDENCE }\end{array} & \text { 2. } \\ & \begin{array}{l}\text { APPROACHING } \\ \text { THE } \\ \text { STANDARD }\end{array} \\ & \\ \text { Pacing reflects } & \text { Provides time } \\ \text { too much or } & \text { for students } \\ \text { too little time } & \text { to complete } \\ \text { for learning } & \text { learning } \\ \text { activities, } & \text { activities. } \\ \text { classroom } & \text { Develops some } \\ \text { business, and } & \text { routines for } \\ \text { transitions. } & \text { classroom } \\ & \text { business and } \\ & \text { most }\end{array}$

3. MEETS THE
STANDARD
Provides
adequate time
for
presentation
and for
completion of
learning
activities.
Paces
instruction

4. ABOVE THE
STANDARD
Paces
instruction to
include
ongoing
review and
closure of
lessons to
connect them
to future
lessons.

5. WELL ABOVE THE STANDARD

Presents, adjusts, and facilitates instruction and daily activities so all students have time for learning, are continually 


$\begin{array}{lll}\begin{array}{ll}\text { transitions are } \\ \text { timely. Uses }\end{array} & \begin{array}{l}\text { and classroom } \\ \text { business to }\end{array} & \begin{array}{l}\text { Classroom } \\ \text { business and } \\ \text { strategies to }\end{array} \\ \text { mace and } & \text { engagintain } & \begin{array}{l}\text { transitions are } \\ \text { efficient and }\end{array} \\ \text { adjust } & \text { Uses } & \text { integrated } \\ \text { instruction to } & \text { transitions to } & \text { into learning } \\ \text { ensure } & \text { support } & \text { activities. } \\ \text { continual } & \text { engagement } & \\ \text { engagement. } & \text { of all } & \\ & \text { students. }\end{array}$

engaged, and

have

opportunities

for reflection

and

assessment.

Supports

students to

self-monitor

time on task.

$\triangleright$ standards

CRITERION SCORE:

5.00

COMMENTS ON THIS CRITERION (OPTIONAL):

used every moment of class could to productively engage students.

3.1 DEMONSTRATING KNOWLEDGE OF SUBJECT MATTER CONTENT AND STUDENT

DEVELOPMENT

1. LITTLE

EVIDENCE

Has a basic

knowledge of

subject mater

and student

development.

Promotes an

understanding

of key

concepts.
APPROACHING

THE

STANDARD

Uses

knowledge of subject matter to identify key concepts and associated

skills.

3. MEETS THE
STANDARD
Communicates
key concepts,
skills, and
themes in an
accurate,
clear, and
coherent
manner.
Builds on
instruction
with students'
cognitive and
linguistic
abilities in

4. ABOVE THE
STANDARD
Uses
expanded
knowledge of
subject
matter to
support
student
understanding
of key
concepts,
themes,
multiple
perspectives,
and

5. WELL ABOVE THE STANDARD

Flexibly uses comprehensive knowledge of subject matter and student development to ensure that all students understand key concepts, themes, multiple perspectives, and 


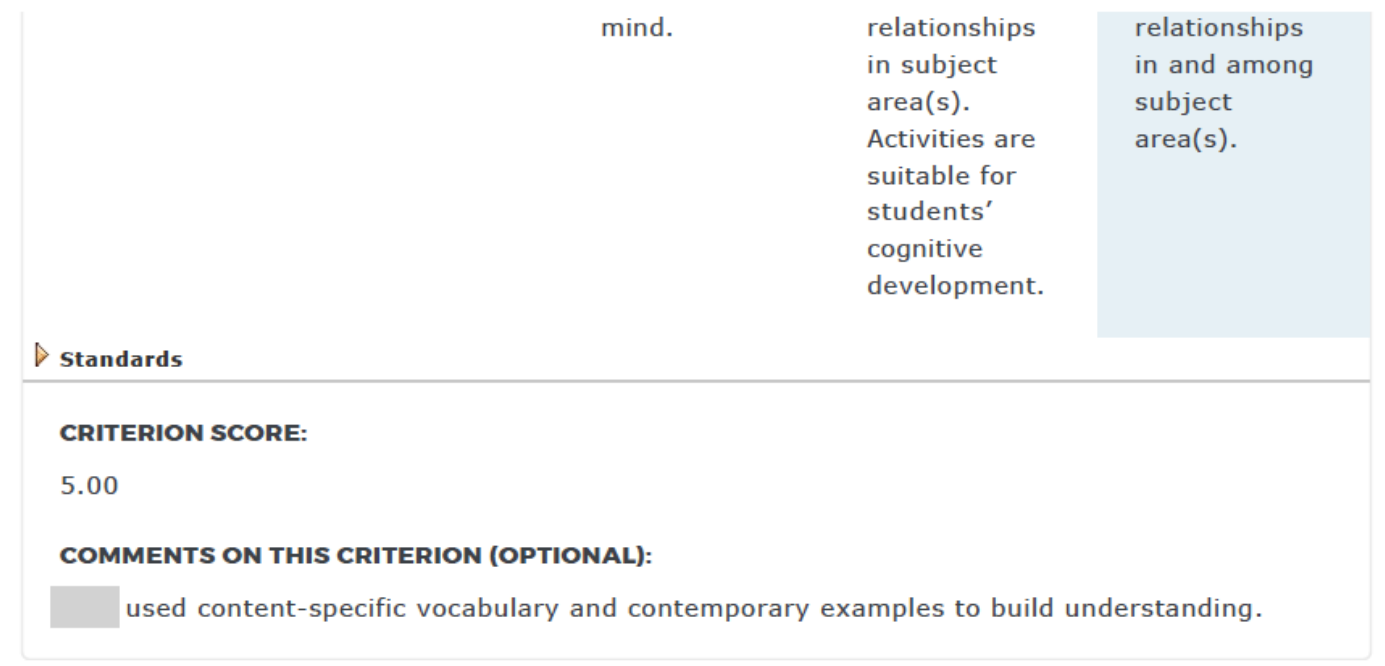

3.2 ORGANIZING CURRICULUM TO SUPPORT STUDENT UNDERSTANDING OF SUBJECT MATTER

\begin{tabular}{|c|c|c|c|c|}
\hline $\begin{array}{l}\text { 1. LITTLE } \\
\text { EVIDENCE }\end{array}$ & $\begin{array}{l}2 . \\
\text { APPROACHING } \\
\text { THE } \\
\text { STANDARD }\end{array}$ & $\begin{array}{l}\text { 3. MEETS THE } \\
\text { STANDARD }\end{array}$ & $\begin{array}{l}\text { 4. ABOVE } \\
\text { THE } \\
\text { STANDARD }\end{array}$ & $\begin{array}{l}\text { 5. WELL } \\
\text { ABOVE THE } \\
\text { STANDARD }\end{array}$ \\
\hline $\begin{array}{l}\text { Demonstrates } \\
\text { some } \\
\text { knowledge of } \\
\text { curriculum to } \\
\text { support } \\
\text { student } \\
\text { understanding. }\end{array}$ & $\begin{array}{l}\text { Uses } \\
\text { knowledge of } \\
\text { subject matter } \\
\text { to promote } \\
\text { students' } \\
\text { understanding } \\
\text { of key } \\
\text { concepts, } \\
\text { skills, and } \\
\text { standards } \\
\text { taught. May } \\
\text { connect key } \\
\text { concepts to } \\
\text { standards and } \\
\text { frameworks. }\end{array}$ & $\begin{array}{l}\text { Identifies key } \\
\text { concepts, } \\
\text { skills, and } \\
\text { units/themes } \\
\text { to facilitate } \\
\text { student } \\
\text { understanding } \\
\text { and reflect } \\
\text { standards and } \\
\text { frameworks. }\end{array}$ & $\begin{array}{l}\text { Organizes } \\
\text { and } \\
\text { sequences } \\
\text { subject } \\
\text { matter to } \\
\text { coordinate } \\
\text { core } \\
\text { curriculum } \\
\text { and content } \\
\text { standards } \\
\text { within and } \\
\text { across } \\
\text { subject } \\
\text { matter as } \\
\text { appropriate. }\end{array}$ & $\begin{array}{l}\text { Designs and } \\
\text { adapts } \\
\text { subject } \\
\text { matter to } \\
\text { demonstrate a } \\
\text { consistent in- } \\
\text { depth student } \\
\text { understanding } \\
\text { of content } \\
\text { and } \\
\text { relationships } \\
\text { among } \\
\text { various } \\
\text { concepts and } \\
\text { themes. } \\
\text { Content } \\
\text { standards are }\end{array}$ \\
\hline
\end{tabular}


CRITERION SCORE:

5.00

COMMENTS ON THIS CRITERION (OPTIONAL):

Extensive scaffolding.

3.3 INTERRELATING IDEAS AND INFORMATION WITHIN AND ACROSS SUBJECT MATTER AREAS

\begin{tabular}{|c|c|c|c|c|}
\hline $\begin{array}{l}\text { 1. LITTLE } \\
\text { EVIDENCE }\end{array}$ & $\begin{array}{l}2 . \\
\text { APPROACHING } \\
\text { THE } \\
\text { STANDARD }\end{array}$ & $\begin{array}{l}\text { 3. MEETS THE } \\
\text { STANDARD }\end{array}$ & $\begin{array}{l}\text { 4. ABOVE THE } \\
\text { STANDARD }\end{array}$ & $\begin{array}{l}\text { 5. WELL } \\
\text { ABOVE THE } \\
\text { STANDARD }\end{array}$ \\
\hline $\begin{array}{l}\text { Focuses on } \\
\text { core } \\
\text { curriculum and } \\
\text { skills. } \\
\text { Attempts to } \\
\text { relate content } \\
\text { to prior } \\
\text { lessons within } \\
\text { the subject } \\
\text { matter. }\end{array}$ & $\begin{array}{l}\text { Identifies key } \\
\text { concepts and } \\
\text { skills in core } \\
\text { curriculum and } \\
\text { standards and } \\
\text { connects } \\
\text { lessons to } \\
\text { previous } \\
\text { learning. }\end{array}$ & $\begin{array}{l}\text { Connects key } \\
\text { concepts, } \\
\text { skills, and } \\
\text { themes within } \\
\text { subject } \\
\text { matter to the } \\
\text { standards. } \\
\text { Builds on } \\
\text { prior lessons } \\
\text { and students' } \\
\text { backgrounds. }\end{array}$ & $\begin{array}{l}\text { Integrates key } \\
\text { concepts, } \\
\text { skills and } \\
\text { underlying } \\
\text { themes within } \\
\text { and across } \\
\text { curriculum to } \\
\text { support } \\
\text { standards. } \\
\text { Capitalizes on } \\
\text { opportunities } \\
\text { to make } \\
\text { connections } \\
\text { while } \\
\text { teaching. }\end{array}$ & $\begin{array}{l}\text { Connects key } \\
\text { concepts and } \\
\text { underlying } \\
\text { themes within } \\
\text { and across } \\
\text { the curriculum } \\
\text { to extend in- } \\
\text { depth learning } \\
\text { for all } \\
\text { students. } \\
\text { Supports } \\
\text { students' } \\
\text { application of } \\
\text { cross- } \\
\text { curricular } \\
\text { learning. }\end{array}$ \\
\hline
\end{tabular}

\section{CRITERION SCORE:}

4.00 


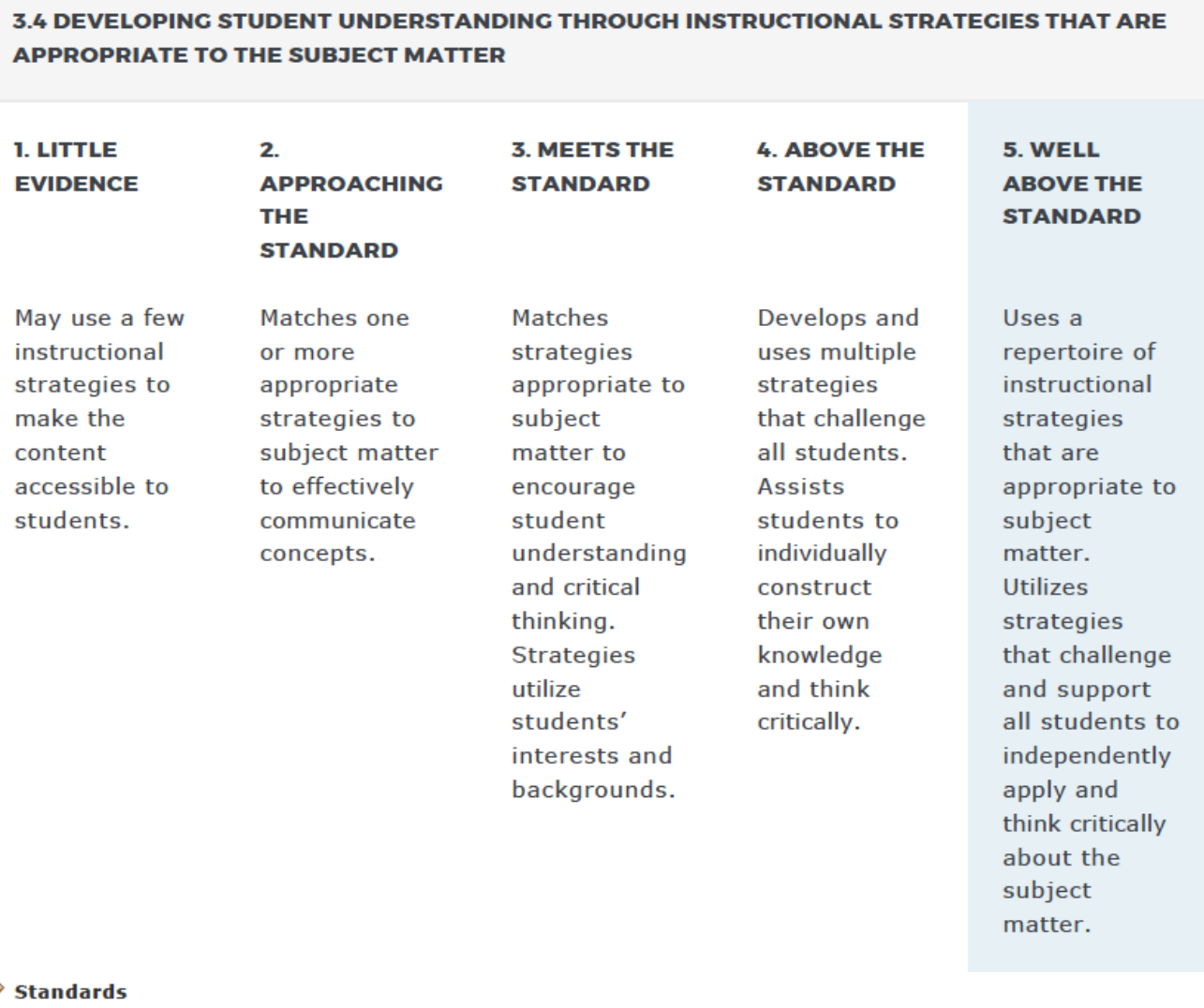

CRITERION SCORE:

5.00

3.5 USING MATERIALS, RESOURCES, AND TECHNOLOGIES TO MAKE SUBJECT MATTER ACCESSIBLE TO STUDENTS

Printed on: 03/23/2017 09:33:12 AM (EST)

$\begin{gathered}\text { clested } \\ \text { witi }\end{gathered} \mid$ t taskstream 


\begin{tabular}{|c|c|c|c|c|}
\hline $\begin{array}{l}\text { 1. LITTLE } \\
\text { EVIDENCE }\end{array}$ & $\begin{array}{l}2 . \\
\text { APPROACHING } \\
\text { THE } \\
\text { STANDARD }\end{array}$ & $\begin{array}{l}\text { 3. MEETS THE } \\
\text { STANDARD }\end{array}$ & $\begin{array}{l}\text { 4. ABOVE THE } \\
\text { STANDARD }\end{array}$ & $\begin{array}{l}\text { 5. WELL } \\
\text { ABOVE THE } \\
\text { STANDARD }\end{array}$ \\
\hline $\begin{array}{l}\text { Uses available } \\
\text { instructional } \\
\text { materials, } \\
\text { resources, } \\
\text { and } \\
\text { technologies } \\
\text { for specific } \\
\text { lessons to } \\
\text { support } \\
\text { student } \\
\text { learning. }\end{array}$ & $\begin{array}{l}\text { Uses } \\
\text { instructional } \\
\text { materials, } \\
\text { resources, and } \\
\text { technologies } \\
\text { to present } \\
\text { concepts and } \\
\text { skills. Some } \\
\text { materials and } \\
\text { resources } \\
\text { reflect } \\
\text { students' } \\
\text { diversity. } \\
\text { Develops some } \\
\text { systems to } \\
\text { provide } \\
\text { equitable } \\
\text { access to } \\
\text { resources. }\end{array}$ & $\begin{array}{l}\text { Selects and } \\
\text { utilizes } \\
\text { appropriate } \\
\text { relevant } \\
\text { instructional } \\
\text { materials, } \\
\text { resources, } \\
\text { and } \\
\text { technologies } \\
\text { to present } \\
\text { concepts and } \\
\text { skills. } \\
\text { Materials } \\
\text { reflect } \\
\text { linguistic } \\
\text { diversity of } \\
\text { students. } \\
\text { Resources are } \\
\text { made available } \\
\text { to all } \\
\text { students. }\end{array}$ & $\begin{array}{l}\text { Selects, } \\
\text { adapts, and } \\
\text { creates a } \\
\text { range of } \\
\text { relevant } \\
\text { materials, } \\
\text { resources, } \\
\text { and } \\
\text { technologies } \\
\text { to enrich } \\
\text { learning, to } \\
\text { reflect } \\
\text { linguistic and } \\
\text { cultural } \\
\text { diversity of } \\
\text { students, and } \\
\text { to provide for } \\
\text { equal access. }\end{array}$ & $\begin{array}{l}\text { Analyzes, } \\
\text { adapts, and } \\
\text { creates a wide } \\
\text { range of } \\
\text { relevant } \\
\text { instructional } \\
\text { materials, } \\
\text { resources, } \\
\text { and } \\
\text { technologies } \\
\text { to extend } \\
\text { students' } \\
\text { understanding } \\
\text { and provide } \\
\text { equal access. } \\
\text { Materials } \\
\text { reflect } \\
\text { diversity } \\
\text { beyond the } \\
\text { classroom. }\end{array}$ \\
\hline \multicolumn{5}{|l|}{ Standards } \\
\hline \multicolumn{5}{|l|}{5.00} \\
\hline \multicolumn{4}{|c|}{ COMMENTS ON THIS CRITERION (OPTIONAL): } & \\
\hline
\end{tabular}

4.I DRAWING ON AND VALUING STUDENTS' BACKGROUNDS, INTERESTS, AND DEVELOPMENTAL LEARNING NEEDS 


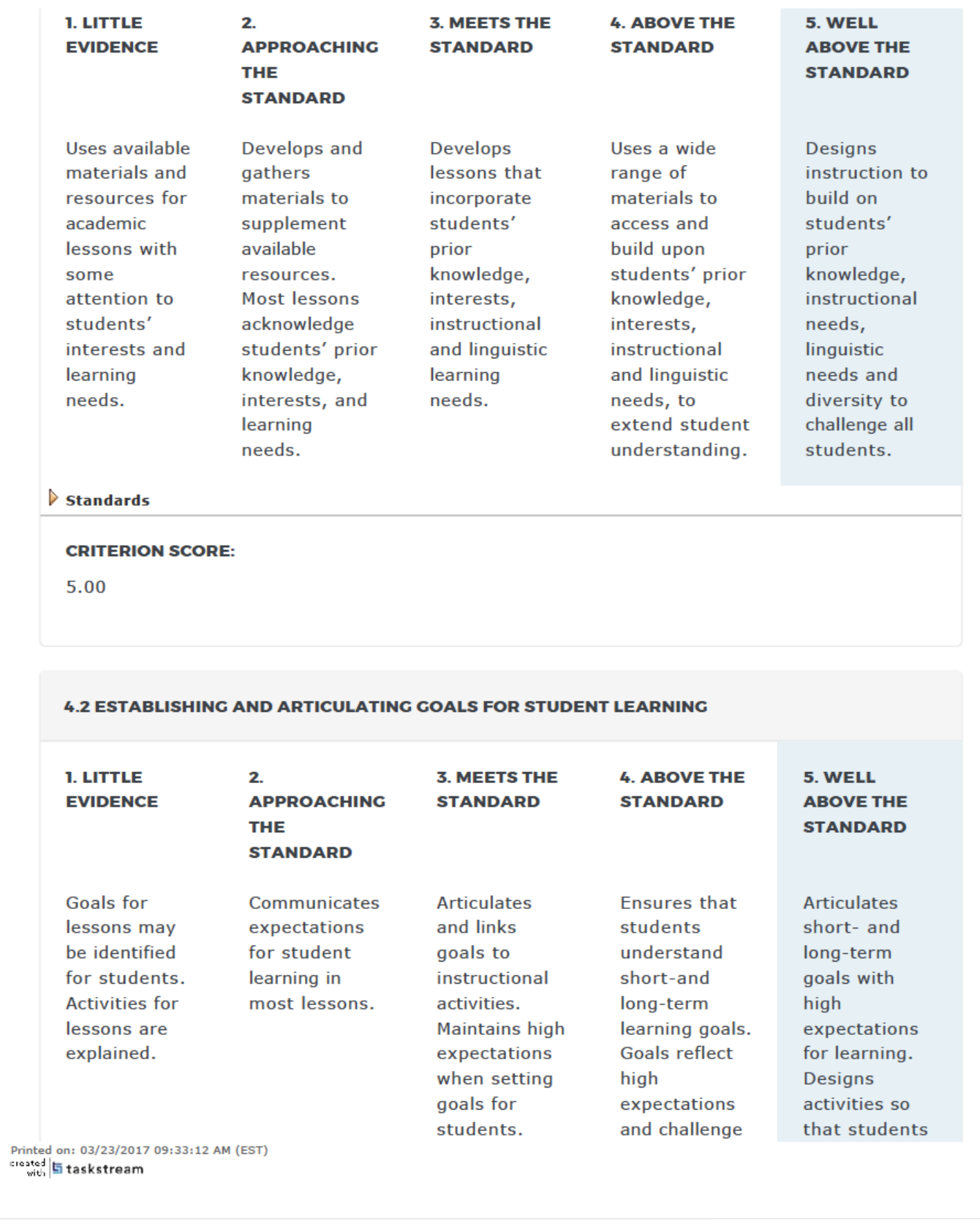




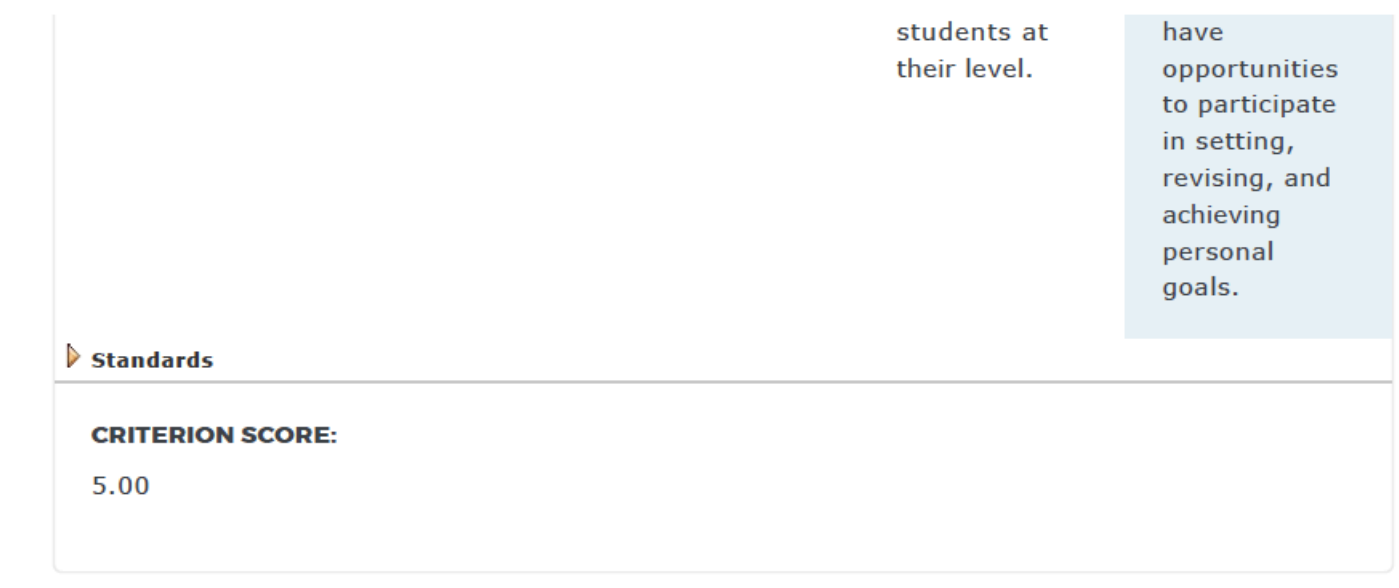

4.3 DEVELOPING AND SEQUENCING INSTRUCTIONAL ACTIVITIES AND MATERIALS FOR STUDENT LEARNING

\begin{tabular}{|c|c|c|c|c|}
\hline $\begin{array}{l}\text { 1. LITTLE } \\
\text { EVIDENCE }\end{array}$ & $\begin{array}{l}2 . \\
\text { APPROACHING } \\
\text { THE } \\
\text { STANDARD }\end{array}$ & $\begin{array}{l}\text { 3. MEETS THE } \\
\text { STANDARD }\end{array}$ & $\begin{array}{l}\text { 4. ABOVE THE } \\
\text { STANDARD }\end{array}$ & $\begin{array}{l}\text { 5. WELL } \\
\text { ABOVE THE } \\
\text { STANDARD }\end{array}$ \\
\hline $\begin{array}{l}\text { Develops } \\
\text { lessons to } \\
\text { address a } \\
\text { particular } \\
\text { concept or } \\
\text { skill utilizing } \\
\text { available } \\
\text { resources. }\end{array}$ & $\begin{array}{l}\text { Develops most } \\
\text { concepts and } \\
\text { skills through } \\
\text { a series of } \\
\text { lessons that } \\
\text { connect and } \\
\text { consider } \\
\text { student } \\
\text { linguistic and } \\
\text { instructional } \\
\text { needs. }\end{array}$ & $\begin{array}{l}\text { Plans } \\
\text { appropriately } \\
\text { sequenced } \\
\text { instruction } \\
\text { and use of } \\
\text { materials to } \\
\text { promote } \\
\text { student } \\
\text { understanding } \\
\text { of basic } \\
\text { concepts and } \\
\text { skills and } \\
\text { considers } \\
\text { linguistic and } \\
\text { instructional } \\
\text { needs. }\end{array}$ & $\begin{array}{l}\text { Develops and } \\
\text { sequences } \\
\text { lessons } \\
\text { appropriate to } \\
\text { subject matter } \\
\text { complexity and } \\
\text { interrelatedness } \\
\text { to ensure } \\
\text { student } \\
\text { learning. }\end{array}$ & $\begin{array}{l}\text { Sequences } \\
\text { instruction to } \\
\text { help students } \\
\text { synthesize } \\
\text { and apply } \\
\text { new } \\
\text { knowledge } \\
\text { and make } \\
\text { connections } \\
\text { within and } \\
\text { across } \\
\text { subject } \\
\text { matter } \\
\text { areas. }\end{array}$ \\
\hline
\end{tabular}

Printed on: 03/23/2017 09:33:12 AM (EST)

:lestod $\mid$ t5 taskstream 
CRITERION SCORE:

5.00

4.4 DESIGNING SHORT-TERM AND LONG-TERM PLANS TO FOSTER STUDENT LEARNING

1. LITTLE EVIDENCE

Plans for daily lessons and activities based on available materials, curriculum outlines, and student content standards.
2.

APPROACHING

THE

STANDARD

\section{Plans for daily} and weekly lessons with attention to unit/shortterm goals and student content standards.

\section{MEETS THE} STANDARD

Develops short-term and long-term plans that organize and link goals with learning activities and student content standards.

\section{ABOVE THE STANDARD}

Designs and sequences short-and long-term plans appropriate to the content.

Plans

integrate

goals, student content standards, and learning activities.
5. WELL ABOVE THE STANDARD

Designs short-term and long-term plans that are comprehensive and cohesive across the content.

Standards

CRITERION SCORE:

5.00

4.5 MODIFYING INSTRUCTIONAL PLANS TO ADJUST FOR STUDENT NEEDS

1. LITTLE EVIDENCE
2.

APPROACHING

THE

STANDARD
3. MEETS THE

STANDARD
4. ABOVE THE

STANDARD
5. WELL ABOVE THE STANDARD 


\begin{tabular}{|c|c|c|c|c|}
\hline $\begin{array}{l}\text { Follows } \\
\text { lessons as } \\
\text { planned. }\end{array}$ & $\begin{array}{l}\text { Adjust lessons } \\
\text { based on } \\
\text { informal } \\
\text { assessment of } \\
\text { student } \\
\text { understanding } \\
\text { and } \\
\text { performance } \\
\text { from previous } \\
\text { lesson, having } \\
\text { taken note of } \\
\text { student } \\
\text { confusions. }\end{array}$ & $\begin{array}{l}\text { Adjusts plans } \\
\text { in advance to } \\
\text { accommodate } \\
\text { levels of } \\
\text { ability and } \\
\text { interests of } \\
\text { most } \\
\text { students. } \\
\text { Makes } \\
\text { modifications } \\
\text { during } \\
\text { lessons to } \\
\text { address } \\
\text { confusions } \\
\text { and individual } \\
\text { student } \\
\text { performance. }\end{array}$ & $\begin{array}{l}\text { Uses } \\
\text { assessments } \\
\text { to inform } \\
\text { modifications } \\
\text { of lessons in } \\
\text { advance. } \\
\text { Throughout } \\
\text { the learning } \\
\text { activity, } \\
\text { assessments } \\
\text { of student } \\
\text { understand } \\
\text { are used to } \\
\text { influence } \\
\text { changes in } \\
\text { instruction. }\end{array}$ & $\begin{array}{l}\text { Uses a wide } \\
\text { range of } \\
\text { assessments to } \\
\text { inform } \\
\text { modifications of } \\
\text { lessons in } \\
\text { advance. Makes } \\
\text { appropriate } \\
\text { modifications } \\
\text { for students } \\
\text { during lessons } \\
\text { and supports } \\
\text { students in } \\
\text { monitoring and } \\
\text { communicating } \\
\text { their own } \\
\text { understanding. }\end{array}$ \\
\hline$\nabla$ standards & & & & \\
\hline
\end{tabular}

CRITERION SCORE:

5.00

COMMENTS ON THIS CRITERION (OPTIONAL):

Made changes based on student performance and reflections.

5.1 ESTABLISHING AND COMMUNICATING LEARNING GOALS FOR ALL STUDENTS

\section{LITTLE} EVIDENCE

Uses available textbooks, resources, and curriculum guidelines to develop learning goals.
2.

APPROACHING

THE STANDARD

Identifies
learning goals
for lessons
utilizing
student
content
standards.
Goals are

3. MEETS THE STANDARD

Articulates
goals based
on student
content
standards.
Clearly
communicates
learning goals

4. ABOVE THE STANDARD

Establishes clear and appropriate goals based on student content standards, with
5. WELL ABOVE THE STANDARD

Integrated learning goals into all learning activities. Establishes, reviews, and revises 


\begin{tabular}{|c|c|c|c|c|}
\hline & $\begin{array}{l}\text { communicated } \\
\text { to students } \\
\text { without } \\
\text { revision. }\end{array}$ & $\begin{array}{l}\text { to students } \\
\text { and families. }\end{array}$ & $\begin{array}{l}\text { consideration } \\
\text { of students' } \\
\text { learning } \\
\text { needs. } \\
\text { Involves } \\
\text { students and } \\
\text { families in } \\
\text { developing } \\
\text { individual } \\
\text { goals to } \\
\text { support } \\
\text { learning. }\end{array}$ & $\begin{array}{l}\text { learning goals } \\
\text { with students } \\
\text { and families } \\
\text { on an ongoing } \\
\text { basis. }\end{array}$ \\
\hline Standards & & & & \\
\hline
\end{tabular}

\section{CRITERION SCORE:}

5.00

COMMENTS ON THIS CRITERION (OPTIONAL):

Up front transparency by providing unit plan to students.

5.2 COLLECTING AND USING MULTIPLE SOURCES OF INFORMATION TO ASSESS STUDENT LEARNING

1. LITTLE EVIDENCE

Uses one or two sources of information to assess student learning and monitor student progress.
2. APPROACHING THE STANDARD

Uses several assessments to monitor student progress.

3. MEETS THE
STANDARD
Develops
strategies to
use
assessment
tools for
monitoring
student
progress and
informing
instruction.

4. ABOVE THE STANDARD

Uses a variety of assessment tools.

Collects, selects, and reflects upon evidence to guide shortand long-term plans and support student
5. WELL ABOVE THE STANDARD
Embeds a wide range of ongoing assessments in instructional activities to provide consistent guidance for planning and instruction. 
$\triangleright$ Standards

CRITERION SCORE:

5.00

5.3 INVOLVING AND GUIDING ALL STUDENTS IN ASSESSING THEIR OWN LEARNING

\begin{tabular}{|c|c|c|c|c|}
\hline 1. LITTLE & 2. & 3. MEETS THE & 4. ABOVE THE & 5. WELL \\
\hline EVIDENCE & $\begin{array}{l}\text { APPROACHING } \\
\text { THE } \\
\text { STANDARD }\end{array}$ & STANDARD & STANDARD & $\begin{array}{l}\text { ABOVE THE } \\
\text { STANDARD }\end{array}$ \\
\hline $\begin{array}{l}\text { Checks and } \\
\text { monitors work } \\
\text { in progress. } \\
\text { Communicates } \\
\text { student } \\
\text { progress } \\
\text { through } \\
\text { school } \\
\text { mandated } \\
\text { procedures. }\end{array}$ & $\begin{array}{l}\text { Provides } \\
\text { students with } \\
\text { feedback on } \\
\text { work in } \\
\text { progress, as } \\
\text { well as } \\
\text { completed } \\
\text { tasks. Some } \\
\text { student } \\
\text { involvement in } \\
\text { correcting } \\
\text { work. }\end{array}$ & $\begin{array}{l}\text { Presents } \\
\text { guidelines for } \\
\text { assessment } \\
\text { to students. } \\
\text { Assists } \\
\text { students in } \\
\text { reflecting on } \\
\text { and assessing } \\
\text { their own } \\
\text { work. }\end{array}$ & $\begin{array}{l}\text { Integrates } \\
\text { student self- } \\
\text { assessment } \\
\text { and reflection } \\
\text { into the } \\
\text { learning } \\
\text { activities. } \\
\text { Students } \\
\text { engage in } \\
\text { some peer } \\
\text { assessment of } \\
\text { work against } \\
\text { criteria. }\end{array}$ & $\begin{array}{l}\text { Engages all } \\
\text { students in } \\
\text { self-and peer } \\
\text { assessment } \\
\text { and in } \\
\text { monitoring } \\
\text { their progress } \\
\text { and goals } \\
\text { over time. }\end{array}$ \\
\hline
\end{tabular}

CRITERION SCORE:

5.00

COMMENTS ON THIS CRITERION (OPTIONAL):

Regular use of self-reflection based on standards.

5.4 USING THE RESULTS OF ASSESSMENT TO GUIDE INSTRUCTION

Printed on: 03/23/2017 09:33:12 AM (EST)

$\begin{gathered}\text { clested } \\ \text { witi }\end{gathered} \mid$ taskstream 


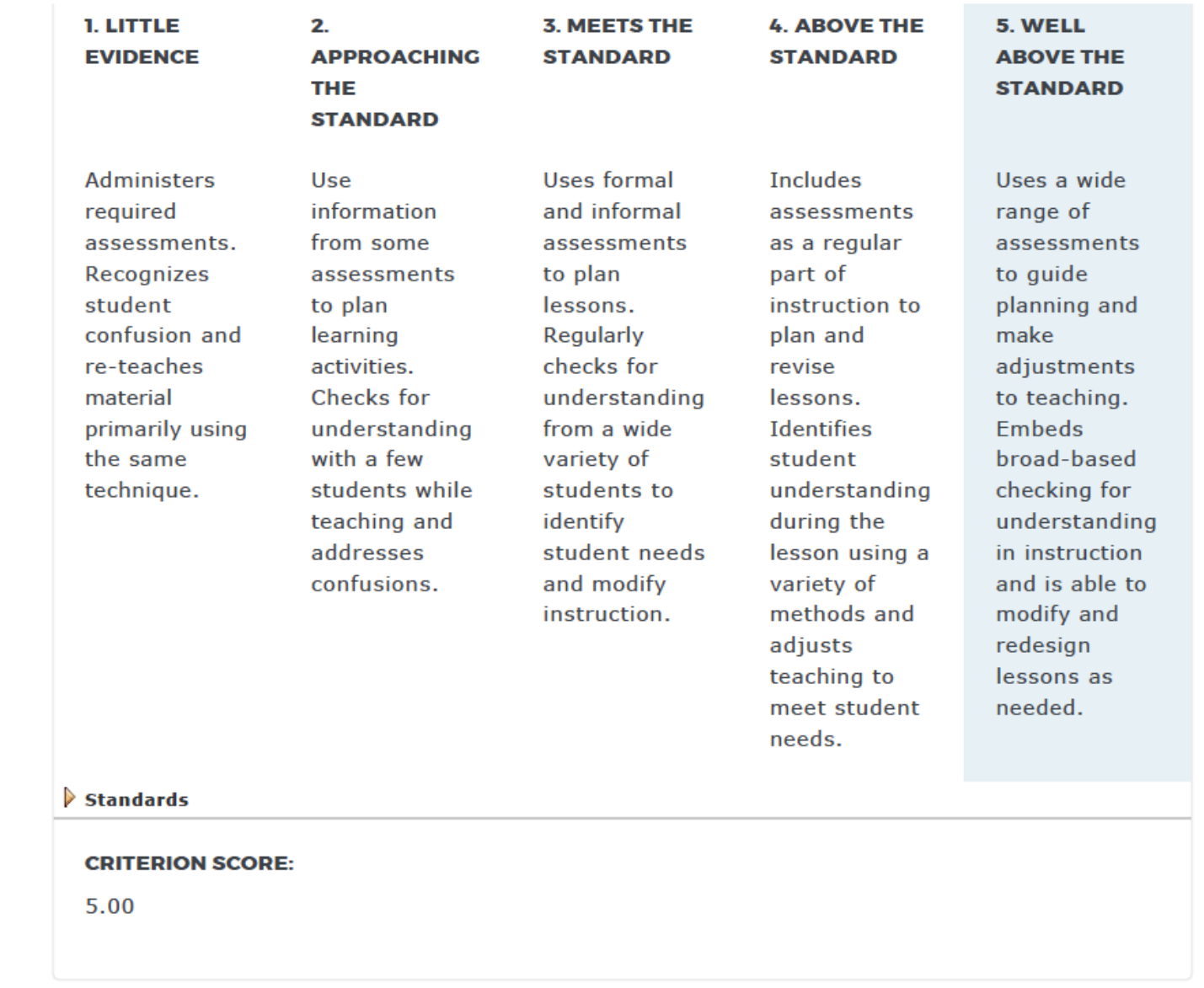

5.5 COMMUNICATING WITH STUDENTS, FAMILIES, AND OTHER AUDIENCES ABOUT STUDENT PROGRESS

\begin{tabular}{|c|c|c|c|c|}
\hline $\begin{array}{l}\text { 1. LITTLE } \\
\text { EVIDENCE }\end{array}$ & $\begin{array}{l}2 . \\
\text { APPROACHING } \\
\text { THE } \\
\text { STANDARD }\end{array}$ & $\begin{array}{l}\text { 3. MEETS THE } \\
\text { STANDARD }\end{array}$ & $\begin{array}{l}\text { 4. ABOVE THE } \\
\text { STANDARD }\end{array}$ & $\begin{array}{l}\text { 5. WELL } \\
\text { ABOVE THE } \\
\text { STANDARD }\end{array}$ \\
\hline $\begin{array}{l}\text { With } \\
\text { cooperating } \\
\text { teacher }\end{array}$ & $\begin{array}{l}\text { With } \\
\text { cooperating } \\
\text { teacher }\end{array}$ & $\begin{array}{l}\text { With } \\
\text { cooperating } \\
\text { teacher }\end{array}$ & $\begin{array}{l}\text { With } \\
\text { cooperating } \\
\text { teacher }\end{array}$ & $\begin{array}{l}\text { With } \\
\text { cooperating } \\
\text { teacher }\end{array}$ \\
\hline
\end{tabular}




\begin{tabular}{|c|c|c|c|c|}
\hline $\begin{array}{l}\text { provides } \\
\text { students and } \\
\text { families with } \\
\text { information } \\
\text { about their } \\
\text { progress } \\
\text { through } \\
\text { school } \\
\text { mandated } \\
\text { procedures. }\end{array}$ & $\begin{array}{l}\text { provides } \\
\text { students with } \\
\text { information } \\
\text { about their } \\
\text { current } \\
\text { progress as } \\
\text { they engage in } \\
\text { learning } \\
\text { activities. } \\
\text { Families and } \\
\text { support } \\
\text { personnel are } \\
\text { contacted as } \\
\text { needed. }\end{array}$ & $\begin{array}{l}\text { provides } \\
\text { students with } \\
\text { information } \\
\text { about their } \\
\text { current } \\
\text { progress and } \\
\text { how to } \\
\text { improve their } \\
\text { work. } \\
\text { Establishes } \\
\text { communication } \\
\text { with families } \\
\text { and support } \\
\text { personnel. }\end{array}$ & $\begin{array}{l}\text { engages } \\
\text { students, } \\
\text { families, and } \\
\text { support } \\
\text { personnel in } \\
\text { regular } \\
\text { discussions } \\
\text { regarding } \\
\text { student } \\
\text { progress and } \\
\text { improvement } \\
\text { plans. } \\
\text { Ongoing } \\
\text { information is } \\
\text { provided from } \\
\text { a variety of } \\
\text { sources for } \\
\text { students, } \\
\text { families, and } \\
\text { support } \\
\text { personnel. }\end{array}$ & $\begin{array}{l}\text { involves } \\
\text { students, } \\
\text { families, and } \\
\text { support } \\
\text { personnel as } \\
\text { partners in } \\
\text { the } \\
\text { assessment } \\
\text { process. } \\
\text { Provides } \\
\text { comprehensive } \\
\text { information } \\
\text { about } \\
\text { students' } \\
\text { progress and } \\
\text { improvement } \\
\text { plans to } \\
\text { students, } \\
\text { families, and } \\
\text { support } \\
\text { personnel. }\end{array}$ \\
\hline Indar & & & & \\
\hline
\end{tabular}

CRITERION SCORE:

4.00

COMMENTS ON THIS CRITERION (OPTIONAL):

Provided student feedback regularly.

\subsection{REFLECTING ON TEACHING PRACTICE AND PLANNING PROFESSIONAL DEVELOPMENT}

\section{LITTLE EVIDENCE}

\section{Reflects on} elements of teaching (e.g., pacing,
2.

APPROACHING

THE

STANDARD

Reflects on
instructional
successes and
dilemmas.

\section{MEETS THE \\ STANDARD \\ Reflects on \\ the \\ relationship of teaching}

4. ABOVE THE STANDARD

Analyzes and reflects on teaching and learning based
5. WELL ABOVE THE STANDARD

Integrates analysis and reflection into daily practice 


\begin{tabular}{|c|c|c|c|c|}
\hline $\begin{array}{l}\text { procedures, } \\
\text { discipline, } \\
\text { movement, } \\
\text { materials, } \\
\text { etc.). }\end{array}$ & $\begin{array}{l}\text { Plans } \\
\text { professional } \\
\text { development } \\
\text { to add to } \\
\text { instructional } \\
\text { strategies and } \\
\text { knowledge of } \\
\text { student } \\
\text { learning. }\end{array}$ & $\begin{array}{l}\text { practice and } \\
\text { student } \\
\text { learning. Plans } \\
\text { professional } \\
\text { development } \\
\text { based on } \\
\text { reflections. }\end{array}$ & $\begin{array}{l}\text { on evidence } \\
\text { gathered } \\
\text { regularly. } \\
\text { Plans } \\
\text { professional } \\
\text { development } \\
\text { based on } \\
\text { reflections } \\
\text { and other } \\
\text { resources. }\end{array}$ & $\begin{array}{l}\text { based on a } \\
\text { wide variety of } \\
\text { evidence in } \\
\text { relationship to } \\
\text { professional } \\
\text { growth and } \\
\text { student } \\
\text { learning. Plans } \\
\text { draw on a } \\
\text { wide variety of } \\
\text { resources to } \\
\text { expand } \\
\text { knowledge. }\end{array}$ \\
\hline$\triangleright$ Standards & & & & \\
\hline
\end{tabular}

CRITERION SCORE:

5.00

6.2 ESTABLISHING PROFESSIONAL GOALS AND PURSUING OPPORTUNITIES TO GROW PROFESSIONALLY

2.

1. LITTLE EVIDENCE

Does not develop goals

through

required

processes.

Attends

required in-

service

trainings.
APPROACHING

THE

STANDARD

Develops goals

through

required

processes.

Attends

required in-

service

trainings.

$\begin{gathered}\text { crostod } \\ \text { witi }\end{gathered} \mid$ t taskstream

\begin{tabular}{|c|c|}
\hline $\begin{array}{l}\text { 4. ABOVE THE } \\
\text { STANDARD }\end{array}$ & $\begin{array}{l}\text { 5. WELL } \\
\text { ABOVE THE } \\
\text { STANDARD }\end{array}$ \\
\hline $\begin{array}{l}\text { Sets short- } \\
\text { term } \\
\text { professional } \\
\text { goals based } \\
\text { on self- } \\
\text { assessment of } \\
\text { effectiveness, } \\
\text { student } \\
\text { learning, and } \\
\text { feedback. } \\
\text { Seeks out } \\
\text { opportunities } \\
\text { to realize } \\
\text { professional }\end{array}$ & $\begin{array}{l}\text { Sets and } \\
\text { modifies } \\
\text { short- and } \\
\text { long-term } \\
\text { goals } \\
\text { considering } \\
\text { self } \\
\text { assessment } \\
\text { and feedback } \\
\text { from a variety } \\
\text { of sources. } \\
\text { Actively } \\
\text { engages in } \\
\text { and }\end{array}$ \\
\hline
\end{tabular}

Sets goals

considering

self-

assessment

and other

feedback.

Expands

knowledge

and skills

through

available

professional

development

opportunities based on a

variety of

relationship to

professional

learning. Plans

expand

knowledge. 


\begin{tabular}{l|l|l}
$\begin{array}{l}\text { (e.g., } \\
\text { workshops, }\end{array}$ & goals. & $\begin{array}{l}\text { contributes to } \\
\text { professional } \\
\text { classes, }\end{array}$ \\
development.
\end{tabular}

$D$ standards

\section{CRITERION SCORE:}

5.00

\section{COMMENTS ON THIS CRITERION (OPTIONAL):}

was well prepared with a strong unit plan, but daily reflected and made changes based on revised goals. not only set goals for the students but met them.

\subsection{WORKING WITH COLLEAGUES TO IMPROVE PROFESSIONAL PRACTICE}

\section{LITTLE EVIDENCE}

Establishes a

positive

working

relationship

with few to no

colleagues.

Interacts

infrequently

with

colleagues to

gather

resources.

Rarely seeks

out trusted

colleagues to

consider

solutions to

problems with

students.
2.

\section{APPROACHING}

THE

STANDARD

Establishes a

positive

working

relationship

with a few

colleagues.

Interacts with

colleagues to

gather

resources.

Seeks out

trusted

colleagues to

consider

solutions to

problems with

students.

4. ABOVE THE
STANDARD
Works
constructively
with
colleagues and
support staff
to improve
student
learning and
reflect on
practice.

5. WELL ABOVE THE STANDARD

Engages staff in dialogue and reflection to support student learning and teacher growth in responsive and appropriate ways. 
Standards

CRITERION SCORE:

4.00

6.4 BALANCING PROFESSIONAL RESPONSIBILITIES AND MAINTAINING MOTIVATION

1. LITTLE

EVIDENCE

Has a positive attitude in the classroom.

Develops an

understanding

of professional

responsibilities.
2.

APPROACHING

THE

STANDARD

Maintains

positive

attitude, demonstrates

understanding

of professional

responsibilities,

and seeks

support to

balance

professional

responsibilities

with personal

needs.
3. MEETS THE

STANDARD

4. ABOVE THE

STANDARD

Maintains

motivation

and

commitment

to all

students,

demonstrates

professional

integrity, and

challenges

self

intellectually

and

creatively.
5. WELL ABOVE THE STANDARD

Maintains

motivation

and

commitment

to all

students and

the

professional

community,

demonstrates

and models

professional

integrity, and

challenges

self

intellectually

and creatively

throughout

career.

$D$ Standards

CRITERION SCORE:

5.00

COMMENTS ON THIS CRITERION (OPTIONAL):

demonstrated personal commitment to the growth of students as well as her own growth each and every day.

rosted 5 taskstream 


\section{Appendix C}

THE

\section{UNIVERSITY}

OF RHODE ISLAND

ALAN SHAWN FEINSTEIN

COLIGE OF EDUCATION

AND PROFESSIONAL STUDIS

THINK BIG 195 WE DO

SCHOOL OF EDUCATION

705 Chafee Hall, 142 Flagg Road, Kingston, RI 02881 USA

December 7, 2016

Dear Alex,

Thank you for your letter requesting access to data collected by the School of Education.

You have done well to explain how you will protect the anonymity of former students. As

the director of the School of Education, I hereby grant you permission to this data.

Sincerely,

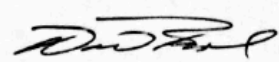

Dr. David Byrd 


\section{Appendix D}

Table 3: Variables Entered/Removed ${ }^{a}$ with HS CT Evaluation as Dependent Variable

Variables Entered/Removed ${ }^{a}$

\begin{tabular}{|c|c|c|c|}
\hline Model & $\begin{array}{c}\text { Variables } \\
\text { Entered }\end{array}$ & $\begin{array}{l}\text { Variables } \\
\text { Removed }\end{array}$ & Method \\
\hline 1 & $\begin{array}{c}\text { Highest ENG } \\
\text { Praxis Score, } \\
\text { EDC GPA at } \\
\text { Admission, } \\
\text { EDC GPA } \\
\text { before } \\
\text { student } \\
\text { teaching, } \\
\text { Highest PLT } \\
\text { Praxis Score, } \\
\text { ENG GPA at } \\
\text { Admission, } \\
\text { ENG GPA } \\
\text { before } \\
\text { Student } \\
\text { teaching }\end{array}$ & . & Enter \\
\hline
\end{tabular}

a. Dependent Variable: HS CT Final (145)

b. All requested variables entered.

Table 4: Model Summary Enter Method with HS CT Evaluation as Dependent

Variable

Model Summary

Adjusted R Std. Error of

\begin{tabular}{ccccc} 
Model & $\mathrm{R}$ & $\mathrm{R}$ Square & Square & the Estimate \\
\hline 1 & $.163^{\mathrm{a}}$ & .026 & -.101 & 19.181
\end{tabular}

a. Predictors: (Constant), Highest ENG Praxis Score, EDC GPA at Admission, EDC GPA before Student teaching, Highest PLT Praxis Score, ENG GPA at Admission, ENG GPA before Student teaching 
Table 5: ANOVA Enter Method with HS CT Evaluation as Dependent Variable

\begin{tabular}{llccccc}
\multicolumn{2}{l}{ ANOVA $^{a}$} \\
\multicolumn{2}{l}{ Model } & Sum of & & & & \\
\hline 1 & Squares & df & Mean Square & F & Sig. \\
\hline & Regression & 460.084 & 6 & 76.681 & .208 & $.972^{\text {b }}$ \\
& Residual & 16923.916 & 46 & 367.911 & & \\
& Total & 17384.000 & 52 & & & \\
\hline
\end{tabular}

a. Dependent Variable: HS CT Final (145)

b. Predictors: (Constant), Highest ENG Praxis Score, EDC GPA at admission, EDC GPA before Student teaching, Highest PLT Praxis Score, ENG GPA at Admission, ENG GPA before Student teaching

Table 6: Coefficients ${ }^{a}$ Enter Method with HS CT Evaluation as Dependent Variable Coefficients $^{a}$

\begin{tabular}{|c|c|c|c|c|c|c|}
\hline \multicolumn{2}{|c|}{ Model } & \multicolumn{2}{|c|}{ Unstandardized Coefficients } & \multirow{2}{*}{$\begin{array}{c}\text { Standardized } \\
\text { Coefficients }\end{array}$} & \multirow[t]{2}{*}{$\mathrm{t}$} & \multirow[t]{2}{*}{ Sig. } \\
\hline & & B & Std. Error & & & \\
\hline \multirow[t]{7}{*}{1} & (Constant) & 61.897 & 76.953 & & .804 & .425 \\
\hline & $\begin{array}{l}\text { EDC GPA@ } \\
\text { Admit }\end{array}$ & -1.568 & 10.406 & -.028 & -.151 & .881 \\
\hline & $\begin{array}{l}\text { ENG GPA@ } \\
\text { Admit }\end{array}$ & 3.919 & 12.988 & .077 & .302 & .764 \\
\hline & $\begin{array}{l}\text { EDC GPA } \\
\text { before } \\
\text { Student } \\
\text { teaching }\end{array}$ & 1.031 & 13.234 & .017 & .078 & .938 \\
\hline & $\begin{array}{l}\text { ENG GPA } \\
\text { before } \\
\text { Student } \\
\text { teaching }\end{array}$ & -6.692 & 16.247 & -.124 & -.412 & .682 \\
\hline & $\begin{array}{l}\text { Highest PLT } \\
\text { Praxis Score }\end{array}$ & .311 & .393 & .158 & .790 & .433 \\
\hline & $\begin{array}{l}\text { Highest ENG } \\
\text { Praxis Score }\end{array}$ & .083 & .547 & .032 & .152 & .880 \\
\hline
\end{tabular}

a. Dependent Variable: HS CT Final (145) 
Appendix E

Table 7: Variables Entered/Removed ${ }^{a}$ Enter Method with MS CT Evaluation as

Dependent Variable

Variables Entered/Removed ${ }^{a}$

\begin{tabular}{cccc}
\hline Model & $\begin{array}{c}\text { Variables } \\
\text { Entered }\end{array}$ & $\begin{array}{c}\text { Variables } \\
\text { Removed }\end{array}$ & Method \\
\hline 1 & Highest ENG &. & Enter \\
Praxis Score, & & \\
EDC GPA at & & \\
Admission, & \\
EDC GPA & \\
before & \\
Student & \\
teaching, & \\
Highest PLT & \\
Praxis Score, & \\
ENG GPA at & \\
Admission, & \\
ENG GPA & \\
before & \\
Student & \\
teaching & \\
\hline
\end{tabular}

a. Dependent Variable: MS CT Final (145)

b. All requested variables entered.

Table 8: Model Summary Enter Method with MS CT Evaluation as Dependent Variable

Model Summary

Adjusted R Std. Error of

Model R R Square Square the Estimate

\begin{tabular}{lllll}
\hline 1 & $.392^{\mathrm{a}}$ & .153 & .023 & 17.4922 \\
\hline
\end{tabular}

a. Predictors: (Constant), Highest ENG Praxis Score, EDC GPA at Admission, EDC GPA before Student teaching, Highest PLT Praxis Score, ENG GPA at Admission, ENG GPA before Student teaching 
Table 9: ANOVA Enter Method with MS CT Evaluation as Dependent Variable

\begin{tabular}{|c|c|c|c|c|c|c|}
\hline Model & & $\begin{array}{l}\text { Sum of } \\
\text { Squares }\end{array}$ & $\mathrm{df}$ & $\begin{array}{c}\text { Mean } \\
\text { Square }\end{array}$ & $\mathrm{F}$ & Sig. \\
\hline \multirow[t]{3}{*}{1} & Regression & 2162.011 & 6 & 360.335 & 1.178 & $.338^{\mathrm{b}}$ \\
\hline & Residual & 11933.103 & 39 & 305.977 & & \\
\hline & Total & 14095.114 & 45 & & & \\
\hline
\end{tabular}

a. Dependent Variable: MS CT Final (145)

b. Predictors: (Constant), Highest ENG Praxis Score, EDC GPA at Admission, EDC GPA before Student teaching, Highest PLT Praxis Score, ENG GPA at Admission, ENG GPA before Student teaching

Table 10: Coefficients ${ }^{a}$ Enter Method with MS CT Evaluation as Dependent Variable Coefficients $^{a}$

\begin{tabular}{|c|c|c|c|c|c|c|}
\hline \multirow[b]{2}{*}{ Model } & & \multicolumn{2}{|c|}{ Unstandardized Coefficients } & \multirow{2}{*}{ 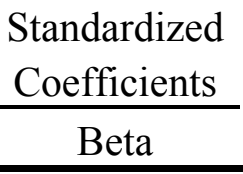 } & \multirow[b]{2}{*}{$\mathrm{t}$} & \multirow[b]{2}{*}{ Sig. } \\
\hline & & $\mathrm{B}$ & Std. Error & & & \\
\hline \multirow[t]{7}{*}{1} & (Constant) & 58.005 & 71.344 & & .813 & .421 \\
\hline & $\begin{array}{l}\text { EDC GPA at } \\
\text { Admission }\end{array}$ & -.102 & 10.173 & -.002 & -.010 & .992 \\
\hline & $\begin{array}{l}\text { ENG GPA at } \\
\text { Admission }\end{array}$ & 8.324 & 13.602 & .157 & .612 & .544 \\
\hline & $\begin{array}{l}\text { EDC GPA } \\
\text { before Student } \\
\text { teaching }\end{array}$ & 19.554 & 13.519 & .310 & 1.446 & .156 \\
\hline & $\begin{array}{l}\text { ENG GPA } \\
\text { before Student } \\
\text { teaching }\end{array}$ & -13.525 & 16.869 & -.238 & -.802 & .428 \\
\hline & $\begin{array}{l}\text { Highest PLT } \\
\text { Praxis Score }\end{array}$ & .662 & .403 & .365 & 1.644 & .108 \\
\hline & $\begin{array}{l}\text { Highest ENG } \\
\text { Praxis Score }\end{array}$ & -.627 & .533 & -.251 & -1.175 & .247 \\
\hline
\end{tabular}

a. Dependent Variable: MS CT Final (145) 
Appendix $F$

Table 11: Variables Entered/Removed ${ }^{a}$ Enter Method with US Evaluation as

Dependent Variable

Variables Entered/Removed ${ }^{a}$

\begin{tabular}{|c|c|c|c|}
\hline Model & $\begin{array}{c}\text { Variables } \\
\text { Entered }\end{array}$ & $\begin{array}{l}\text { Variables } \\
\text { Removed }\end{array}$ & Method \\
\hline 1 & $\begin{array}{c}\text { Highest ENG } \\
\text { Praxis Score, } \\
\text { EDC GPA at } \\
\text { Admission, } \\
\text { EDC GPA } \\
\text { before } \\
\text { Student } \\
\text { teaching, } \\
\text { Highest PLT } \\
\text { Praxis Score, } \\
\text { ENG GPA at } \\
\text { Admission, } \\
\text { ENG GPA } \\
\text { before } \\
\text { Student } \\
\text { teaching }\end{array}$ & & Enter \\
\hline
\end{tabular}

a. Dependent Variable: US Final Eval (145)

b. All requested variables entered.

Table 12: Model Summary Enter Method with US Evaluation as Dependent Variable

Model Summary

\begin{tabular}{lcccc}
\hline Model & R & R Square & $\begin{array}{c}\text { Adjusted R } \\
\text { Square }\end{array}$ & $\begin{array}{c}\text { Std. Error of } \\
\text { the Estimate }\end{array}$ \\
\hline 1 & $.309^{\mathrm{a}}$ & .096 & -.022 & 16.6972 \\
\hline
\end{tabular}

a. Predictors: (Constant), Highest ENG Praxis Score, EDC

GPA at Admission, EDC GPA before Student teaching, Highest PLT Praxis Score, ENG GPA at Admission, ENG

GPA before Student teaching 
Table 13: ANOVA Enter Method with US Evaluation as Dependent Variable

\begin{tabular}{|c|c|c|c|c|c|c|}
\hline Model & & $\begin{array}{l}\text { Sum of } \\
\text { Squares }\end{array}$ & $\mathrm{df}$ & $\begin{array}{c}\text { Mean } \\
\text { Square }\end{array}$ & $\mathrm{F}$ & Sig. \\
\hline \multirow[t]{3}{*}{$\overline{1}$} & Regression & 1357.834 & 6 & 226.306 & .812 & $.566^{\mathrm{b}}$ \\
\hline & Residual & 12824.684 & 46 & 278.797 & & \\
\hline & Total & 14182.519 & 52 & & & \\
\hline
\end{tabular}

a. Dependent Variable: US Final Eval (145)

b. Predictors: (Constant), Highest ENG Praxis Score, EDC GPA at Admission, EDC GPA before Student teaching, Highest PLT Praxis Score, ENG GPA at Admission, ENG GPA before Student teaching

Table 14: Coefficients ${ }^{a}$ Enter Method with US Evaluation as Dependent Variable

Coefficients $^{a}$

\begin{tabular}{|c|c|c|c|c|c|c|}
\hline \multirow[b]{2}{*}{ Model } & & \multicolumn{2}{|c|}{ Unstandardized Coefficients } & \multirow{2}{*}{$\begin{array}{l}\text { Standardized } \\
\text { Coefficients } \\
\text { Beta }\end{array}$} & \multirow[b]{2}{*}{$\mathrm{t}$} & \multirow[b]{2}{*}{ Sig. } \\
\hline & & $\mathrm{B}$ & Std. Error & & & \\
\hline \multirow[t]{7}{*}{1} & (Constant) & 25.425 & 66.988 & & .380 & .706 \\
\hline & $\begin{array}{l}\text { EDC GPA at } \\
\text { Admission }\end{array}$ & 6.156 & 9.059 & .122 & .680 & .500 \\
\hline & $\begin{array}{l}\text { ENG GPA at } \\
\text { Admission }\end{array}$ & -2.134 & 11.306 & -.046 & -.189 & .851 \\
\hline & $\begin{array}{l}\text { EDC GPA before } \\
\text { Student teaching }\end{array}$ & 4.660 & 11.520 & .087 & .405 & .688 \\
\hline & $\begin{array}{l}\text { ENG GPA before } \\
\text { Student teaching }\end{array}$ & -7.071 & 14.143 & -.145 & -.500 & .619 \\
\hline & $\begin{array}{l}\text { Highest PLT } \\
\text { Praxis Score }\end{array}$ & .614 & .342 & .345 & $\begin{array}{c}1.79 \\
5\end{array}$ & .079 \\
\hline & $\begin{array}{l}\text { Highest ENG } \\
\text { Praxis Score }\end{array}$ & -.103 & .477 & -.043 & -.216 & .830 \\
\hline
\end{tabular}

a. Dependent Variable: US Final Eval (145) 


\section{Appendix $G$}

Table 15: Variables Entered/Removed ${ }^{a}$ Enter Method with Sum Score of Evaluations as Dependent Variable

Variables Entered/Removed ${ }^{a}$

\begin{tabular}{cccc}
\hline Model & $\begin{array}{c}\text { Variables } \\
\text { Entered }\end{array}$ & $\begin{array}{c}\text { Variables } \\
\text { Removed }\end{array}$ & Method \\
\hline 1 & Highest ENG &. & Enter \\
Praxis Score, & & \\
EDC GPA at & & \\
Admission, & \\
EDC GPA & \\
before & \\
Student & \\
teaching, & \\
Highest PLT & \\
Praxis Score, & \\
ENG GPA at & \\
Admission, \\
ENG GPA \\
before \\
Student \\
teaching ${ }^{\text {b }}$
\end{tabular}

a. Dependent Variable: Sum Score

b. All requested variables entered.

Table 16: Model Summary Enter Method with Sum Score of Evaluations as Dependent Variable

Model Summary

\begin{tabular}{lcccc}
\hline Model & $\mathrm{R}$ & R Square & $\begin{array}{c}\text { Adjusted R } \\
\text { Square }\end{array}$ & $\begin{array}{c}\text { Std. Error of } \\
\text { the Estimate }\end{array}$ \\
\hline 1 & $.288^{\mathrm{a}}$ & .083 & -.037 & 73.3704 \\
\hline
\end{tabular}

a. Predictors: (Constant), Highest ENG Praxis Score, EDC GPA at Admission, EDC GPA before Student teaching, Highest PLT Praxis Score, ENG GPA at Admission, ENG GPA before Student teaching 
Table 17: ANOVA Enter Method with Sum Score of Evaluations as Dependent

Variable

ANOVA $A^{a}$

\begin{tabular}{llccccc}
\hline \multicolumn{1}{c}{ Model } & & Sum of & & & & \\
\hline 1 & Regression & 22420.351 & 6 & 3736.725 & .694 & $.655^{\mathrm{b}}$ \\
& Residual & 247628.130 & 46 & 5383.220 & & \\
& Total & 270048.481 & 52 & & & \\
\hline
\end{tabular}

a. Dependent Variable: Sum Score

b. Predictors: (Constant), Highest ENG Praxis Score, EDC GPA at

Admission, EDC GPA before Student teaching, Highest PLT Praxis Score,

ENG GPA at Admission, ENG GPA before Student teaching

Table 18: Coefficients ${ }^{a}$ Enter Method with Sum Score of Evaluations as Dependent

Variable

Coefficients $^{a}$

\begin{tabular}{|c|c|c|c|c|c|c|}
\hline \multirow[b]{2}{*}{ Model } & & \multicolumn{2}{|c|}{ Unstandardized Coefficients } & \multirow{2}{*}{$\begin{array}{c}\begin{array}{c}\text { Standardized } \\
\text { Coefficients }\end{array} \\
\text { Beta } \\
\end{array}$} & \multirow[b]{2}{*}{$\mathrm{t}$} & \multirow[b]{2}{*}{ Sig. } \\
\hline & & $\mathrm{B}$ & Std. Error & & & \\
\hline \multirow[t]{7}{*}{1} & (Constant) & -59.415 & 294.357 & & -.202 & .841 \\
\hline & $\begin{array}{l}\text { EDC GPA at } \\
\text { Admission }\end{array}$ & -22.362 & 39.805 & -.102 & -.562 & .577 \\
\hline & $\begin{array}{l}\text { ENG GPA at } \\
\text { Admission }\end{array}$ & 23.084 & 49.680 & .115 & .465 & .644 \\
\hline & $\begin{array}{l}\text { EDC GPA before } \\
\text { Student teaching }\end{array}$ & 27.738 & 50.621 & .118 & .548 & .586 \\
\hline & $\begin{array}{l}\text { ENG GPA before } \\
\text { Student teaching }\end{array}$ & -2.476 & 62.149 & -.012 & -.040 & .968 \\
\hline & $\begin{array}{l}\text { Highest PLT } \\
\text { Praxis Score }\end{array}$ & .958 & 1.503 & .123 & .637 & .527 \\
\hline & $\begin{array}{l}\text { Highest ENG } \\
\text { Praxis Score }\end{array}$ & .676 & 2.094 & .065 & .323 & .748 \\
\hline
\end{tabular}

a. Dependent Variable: Sum Score 


\section{Appendix $H$}

Table 19: Descriptive Statistics for Each Variable

Descriptive Statistics

\begin{tabular}{|c|c|c|c|c|c|}
\hline & $\mathrm{N}$ & Minimum & Maximum & Mean & Std. Deviation \\
\hline $\begin{array}{l}\text { EDC GPA at } \\
\text { Admission }\end{array}$ & 53 & 2.65 & 4.00 & 3.7370 & .32832 \\
\hline $\begin{array}{l}\text { ENG GPA at } \\
\text { Admission }\end{array}$ & 53 & 2.72 & 4.00 & 3.5457 & .35969 \\
\hline $\begin{array}{l}\text { EDC GPA before } \\
\text { Student teaching }\end{array}$ & 53 & 2.64 & 4.00 & 3.7217 & .30738 \\
\hline $\begin{array}{l}\text { ENG GPA before } \\
\text { Student teaching }\end{array}$ & 53 & 2.51 & 4.00 & 3.4789 & .33771 \\
\hline $\begin{array}{l}\text { Highest PLT Praxis } \\
\text { Score }\end{array}$ & 53 & 158 & 197 & 174.98 & 9.283 \\
\hline $\begin{array}{l}\text { Highest ENG Praxis } \\
\text { Score }\end{array}$ & 53 & 166 & 192 & 176.11 & 6.963 \\
\hline HS CT Final (145) & 53 & 84 & 145 & 119.50 & 18.284 \\
\hline MS CT Final (145) & 46 & 69.0 & 145.0 & 118.054 & 17.6982 \\
\hline US Final Eval (145) & 53 & 88.5 & 145.0 & 122.934 & 16.5149 \\
\hline Sum Score & 53 & 195.0 & 427.0 & 320.019 & 72.0641 \\
\hline Valid N (listwise) & 46 & & & & \\
\hline
\end{tabular}


Appendix I

Table 20: Correlations between Pre-Service Benchmarks and Student Teaching Variables

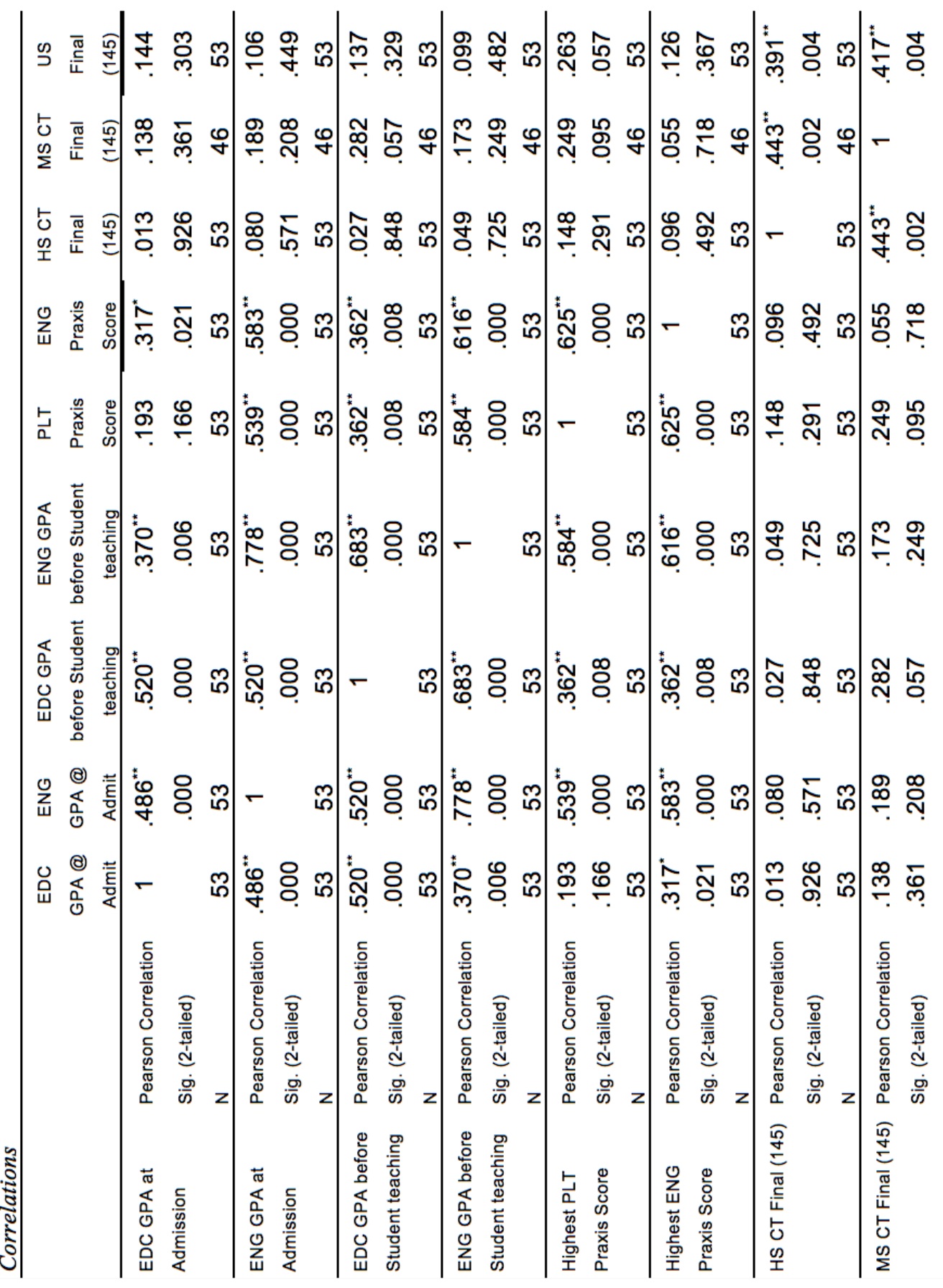




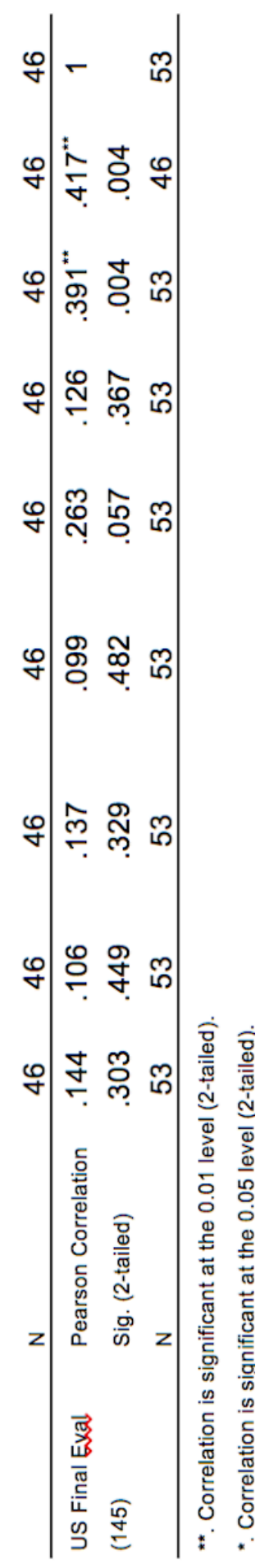




\section{Appendix $J$}

Table 21: Descriptive Statistics of Education Grade Point Averages and Principles of Learning and Teaching Praxis Scores

Descriptive Statistics

\begin{tabular}{lccc}
\hline & Mean & Std. Deviation & $\mathrm{N}$ \\
\hline EDC GPA at Admission & 3.7370 & .32832 & 53 \\
EDC GPA before Student & 3.7217 & .30738 & 53 \\
teaching & & & \\
Highest PLT Praxis Score & 174.98 & 9.283 & 53 \\
\hline
\end{tabular}

Table 22: Correlations between Education Grade Point Averages and Principles of Learning and Teaching Praxis Scores

Correlations

\begin{tabular}{llccc}
\hline & & $\begin{array}{c}\text { EDC GPA at } \\
\text { Admission }\end{array}$ & $\begin{array}{c}\text { EDC GPA before } \\
\text { Student teaching }\end{array}$ & $\begin{array}{c}\text { PLT Praxis } \\
\text { Score }\end{array}$ \\
\hline \multirow{2}{*}{ EDC GPA at Admission } & Pearson Correlation & 1 & $.520^{* *}$ & .193 \\
& Sig. (2-tailed) & & .000 & .166 \\
& $\mathrm{~N}$ & 53 & 53 & 53 \\
\hline EDC GPA before & Pearson Correlation & $.520^{* *}$ & 1 & $.362^{* *}$ \\
Student teaching & Sig. (2-tailed) & .000 & & .008 \\
& $\mathrm{~N}$ & 53 & 53 & 53 \\
\hline PLT Praxis Score & Pearson Correlation & .193 & $.362^{* *}$ & 1 \\
& Sig. (2-tailed) & .166 & .008 & \\
& $\mathrm{~N}$ & 53 & 53 & 53 \\
\hline
\end{tabular}

${ }^{* *}$. Correlation is significant at the 0.01 level (2-tailed). 


\section{Appendix $K$}

Table 23: Descriptive Statistics of English Grade Point Averages and English

Language Arts Praxis Score

Descriptive Statistics

\begin{tabular}{lccc}
\hline & Mean & Std. Deviation & $\mathrm{N}$ \\
\hline ENG GPA at Admission & 3.5457 & .35969 & 53 \\
ENG GPA before Student & 3.4789 & .33771 & 53 \\
teaching & & & \\
Highest ENG Praxis Score & 176.11 & 6.963 & 53 \\
\hline
\end{tabular}

Table 24: Correlations between English Grade Point Averages and English Language Arts Praxis Score

Correlations

\begin{tabular}{|c|c|c|c|c|}
\hline & & $\begin{array}{l}\text { ENG GPA } \\
\text { at } \\
\text { Admission }\end{array}$ & $\begin{array}{c}\text { ENG GPA } \\
\text { before Student } \\
\text { teaching }\end{array}$ & $\begin{array}{c}\text { ENG Praxis } \\
\text { Score }\end{array}$ \\
\hline \multirow{4}{*}{$\begin{array}{l}\text { ENG GPA at } \\
\text { Admission }\end{array}$} & Pearson & 1 & $.778^{* *}$ & $.583^{* *}$ \\
\hline & Correlation & & & \\
\hline & Sig. (2-tailed) & & .000 & .000 \\
\hline & $\mathrm{N}$ & 53 & 53 & 53 \\
\hline \multirow{4}{*}{$\begin{array}{l}\text { ENG GPA before } \\
\text { Student teaching }\end{array}$} & Pearson & $.778^{* *}$ & 1 & $.616^{* *}$ \\
\hline & Correlation & & & \\
\hline & Sig. (2-tailed) & .000 & & .000 \\
\hline & $\mathrm{N}$ & 53 & 53 & 53 \\
\hline \multirow[t]{4}{*}{ ENG Praxis Score } & Pearson & $.583^{* *}$ & $.616^{* *}$ & 1 \\
\hline & Correlation & & & \\
\hline & Sig. (2-tailed) & .000 & .000 & \\
\hline & $\mathrm{N}$ & 53 & 53 & 53 \\
\hline
\end{tabular}

**. Correlation is significant at the 0.01 level (2-tailed). 
Appendix L

Table 25: Descriptive Statistics of Student Teaching Variables

$\underline{\text { Descriptive Statistics }}$

\begin{tabular}{lccc}
\hline & \multicolumn{3}{c}{ Std. } \\
\hline $\begin{array}{l}\text { HS CT Final } \\
(145)\end{array}$ & 119.50 & 18.284 & 53 \\
$\begin{array}{l}\text { MS CT Final } \\
(145)\end{array}$ & 118.054 & 17.6982 & 46 \\
$\begin{array}{l}\text { US Final Eval } \\
(145)\end{array}$ & 122.934 & 16.5149 & 53 \\
\hline
\end{tabular}

Table 26: Correlations of Student Teaching Variables

Correlations

\begin{tabular}{llccc}
\hline & & $\begin{array}{c}\text { HS CT Final } \\
(145)\end{array}$ & $\begin{array}{c}\text { MS CT Final } \\
(145)\end{array}$ & $\begin{array}{c}\text { US Final } \\
\text { Eval (145) }\end{array}$ \\
\hline HS CT Final & Pearson & 1 & $.443^{* *}$ & $.391^{* *}$ \\
$(145)$ & Correlation & & & \\
& Sig. (2-tailed) & & .002 & .004 \\
& $\mathrm{~N}$ & 53 & 46 & 53 \\
\hline MS CT Final & Pearson & $.443^{* *}$ & 1 & $.417^{* *}$ \\
$(145)$ & Correlation & & & \\
& Sig. (2-tailed) & .002 & & .004 \\
& $\mathrm{~N}$ & 46 & 46 & 46 \\
\hline US Final Eval & Pearson & $.391^{* *}$ & $.417^{* *}$ & 1 \\
$(145)$ & Correlation & & & \\
& Sig. (2-tailed) & .004 & .004 & \\
& $\mathrm{~N}$ & 53 & 46 & 53 \\
\hline
\end{tabular}

**. Correlation is significant at the 0.01 level (2-tailed). 
Appendix M

Table 27: Correlations with Sum Score of Evaluations

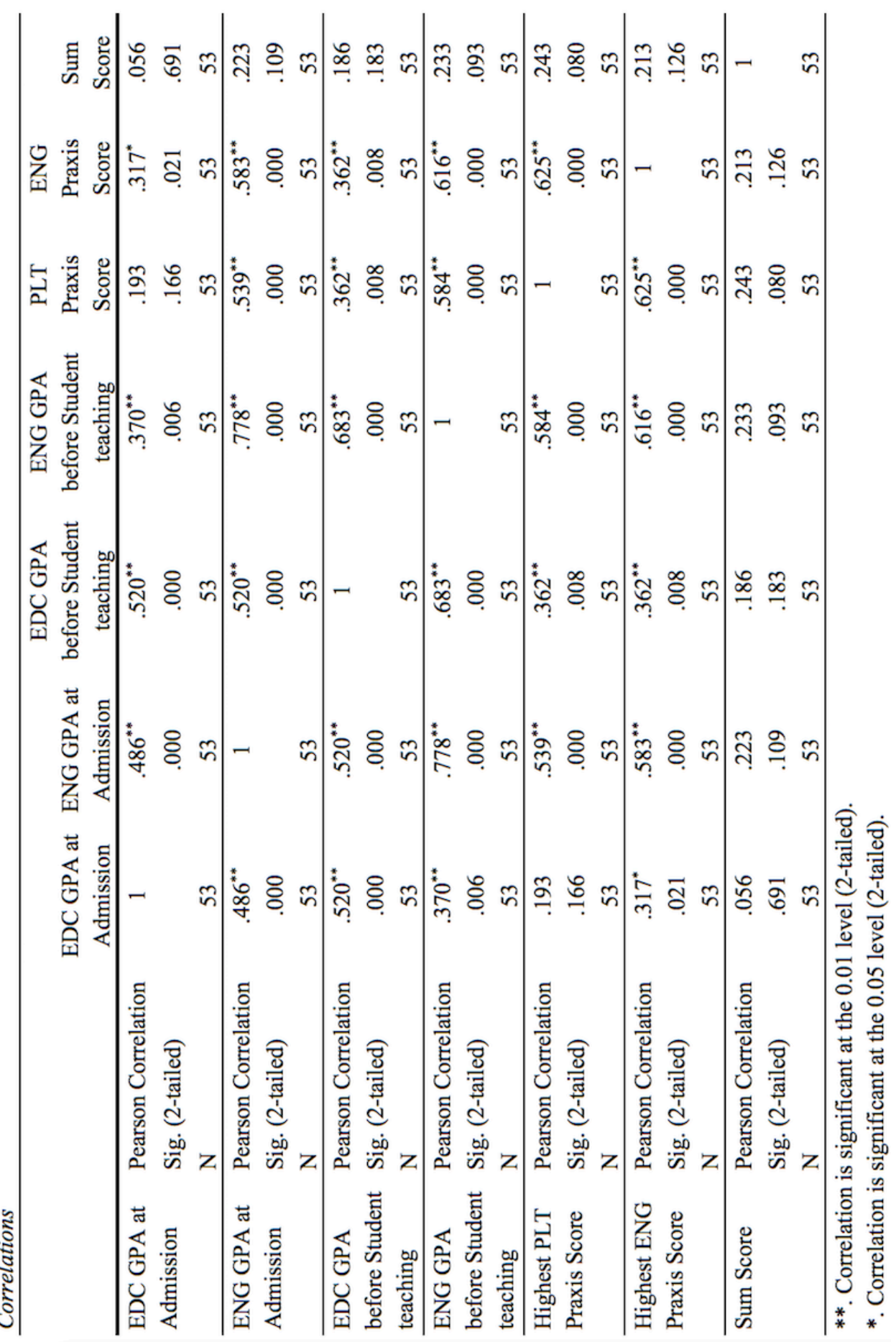




\section{Appendix $N$}

Table 28: Variables Entered/Removed ${ }^{a}$ with PLT Praxis Score as Dependent Variable Variables Entered/Removed ${ }^{a}$

\begin{tabular}{|c|c|c|c|}
\hline Model & $\begin{array}{l}\text { Variables } \\
\text { Entered }\end{array}$ & $\begin{array}{l}\text { Variables } \\
\text { Removed }\end{array}$ & Method \\
\hline 1 & $\begin{array}{c}\text { EDC GPA } \\
\text { before } \\
\text { Student } \\
\text { teaching, } \\
\text { EDC GPA at } \\
\text { admission }\end{array}$ & . & Enter \\
\hline
\end{tabular}

a. Dependent Variable: Highest PLT Praxis

Score

b. All requested variables entered.

Table 29: Model Summary with PLT Praxis Score as Dependent Variable

Model Summary

\begin{tabular}{lcccc}
\hline Model & $\mathrm{R}$ & R Square & $\begin{array}{c}\text { Adjusted R } \\
\text { Square }\end{array}$ & $\begin{array}{c}\text { Std. Error of } \\
\text { the Estimate }\end{array}$ \\
\hline 1 & $.362^{\mathrm{a}}$ & .131 & .096 & 8.824 \\
\hline
\end{tabular}

a. Predictors: (Constant), EDC GPA before Student teaching, EDC GPA at admission

Table 30: ANOVA ${ }^{a}$ with PLT Praxis Score as Dependent Variable

\begin{tabular}{llccccc}
\multicolumn{2}{l}{ ANOVA $^{a}$} \\
\multicolumn{2}{l}{ Model } & $\begin{array}{l}\text { Sum of } \\
\text { Squares }\end{array}$ & df & Mean Square & F & Sig. \\
\hline 1 & Regression & 587.535 & 2 & 293.767 & 3.773 & $.030^{\mathrm{b}}$ \\
& Residual & 3893.447 & 50 & 77.869 & & \\
& Total & 4480.981 & 52 & & & \\
\hline
\end{tabular}

a. Dependent Variable: Highest PLT Praxis Score

b. Predictors: (Constant), EDC GPA before Student teaching, EDC GPA at admission 
Table 31: Coefficients ${ }^{a}$ with PLT Praxis Score as Dependent Variable

Coefficients $^{a}$

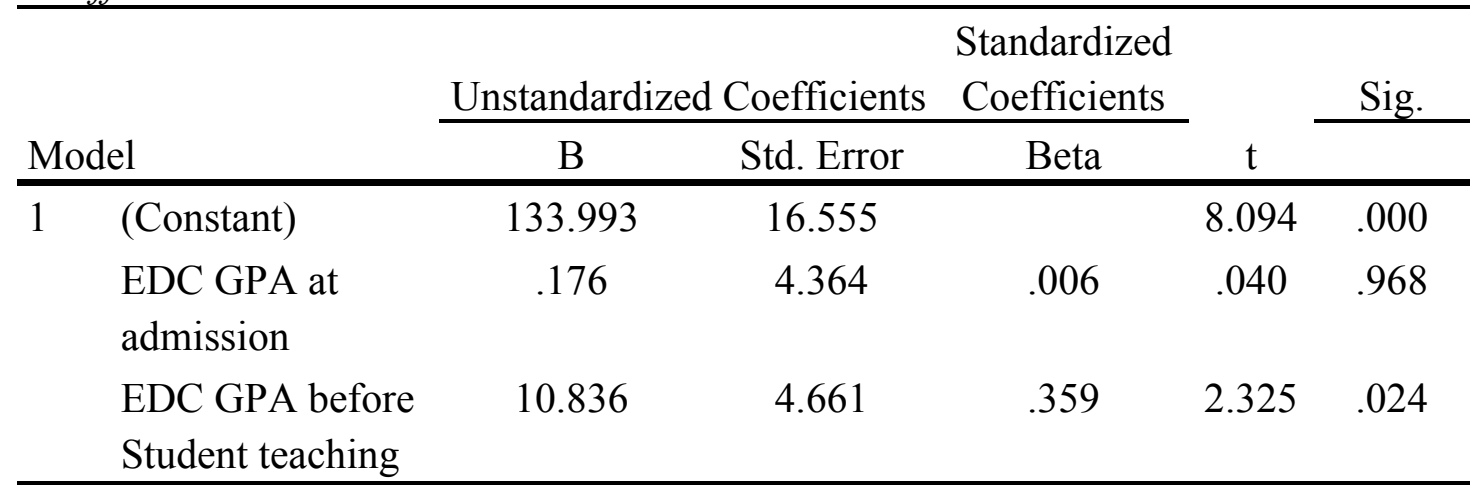

a. Dependent Variable: Highest PLT Praxis Score

Table 32. Variables Entered/Removed ${ }^{a}$ with ENG Praxis Score as Dependent Variable

Variables Entered/Removed ${ }^{a}$

\begin{tabular}{lccc}
\hline Model & Variables & Variables & \\
Entered & Removed & Method \\
\hline 1 & ENG GPA & $\cdot$ & Enter \\
before & & \\
Student & & \\
teaching, & & \\
ENG GPA at & & \\
admission & \\
\end{tabular}

a. Dependent Variable: Highest ENG Praxis

Score

b. All requested variables entered.

Table 33: Model Summary with ENG Praxis Score as Dependent Variable

Model Summary

\begin{tabular}{lcccc}
\hline Model & $\mathrm{R}$ & R Square & $\begin{array}{c}\text { Adjusted R } \\
\text { Square }\end{array}$ & $\begin{array}{c}\text { Std. Error of } \\
\text { the Estimate }\end{array}$ \\
\hline 1 & $.638^{\mathrm{a}}$ & .406 & .383 & 5.471 \\
\hline
\end{tabular}

a. Predictors: (Constant), ENG GPA before Student teaching, ENG GPA at admission 
Table 34: ANOVA ${ }^{a}$ with ENG Praxis Score as Dependent Variable

\begin{tabular}{|c|c|c|c|c|c|c|}
\hline Model & & $\begin{array}{l}\text { Sum of } \\
\text { Squares }\end{array}$ & $\mathrm{df}$ & Mean Square & $\mathrm{F}$ & Sig. \\
\hline \multirow[t]{3}{*}{$\overline{1}$} & Regression & 1024.788 & 2 & 512.394 & 17.119 & $.000^{\mathrm{b}}$ \\
\hline & Residual & 1496.533 & 50 & 29.931 & & \\
\hline & Total & 2521.321 & 52 & & & \\
\hline
\end{tabular}

a. Dependent Variable: Highest ENG Praxis Score

b. Predictors: (Constant), ENG GPA before Student teaching, ENG GPA at admission

Table 35: Coefficients ${ }^{a}$ with ENG Praxis Score as Dependent Variable

Coefficients $^{a}$

\begin{tabular}{|c|c|c|c|c|c|c|}
\hline \multirow{2}{*}{\multicolumn{2}{|c|}{ Model }} & \multicolumn{2}{|c|}{ Unstandardized Coefficients } & \multirow{2}{*}{$\begin{array}{c}\text { Standardized } \\
\text { Coefficients } \\
\text { Beta }\end{array}$} & \multirow[b]{2}{*}{$\mathrm{t}$} & \multirow[b]{2}{*}{ Sig. } \\
\hline & & $\mathrm{B}$ & Std. Error & & & \\
\hline \multirow[t]{3}{*}{1} & (Constant) & 128.568 & 8.161 & & 15.754 & .000 \\
\hline & $\begin{array}{l}\text { ENG GPA at } \\
\text { admission }\end{array}$ & 5.069 & 3.356 & .262 & 1.510 & .137 \\
\hline & $\begin{array}{l}\text { ENG GPA before } \\
\text { Student teaching }\end{array}$ & 8.501 & 3.574 & .412 & 2.378 & .021 \\
\hline
\end{tabular}

a. Dependent Variable: Highest ENG Praxis Score 
Table 36: Descriptive Statistics Skewness of Variables

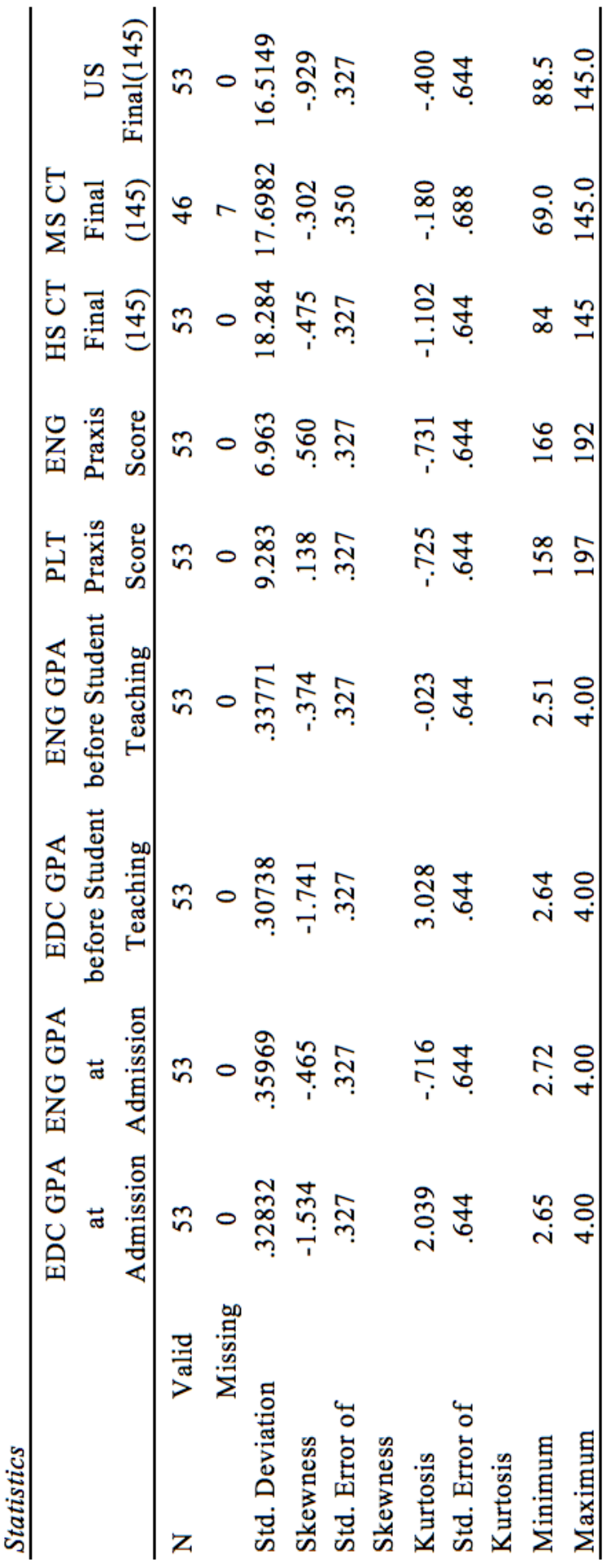




\section{BIBLIOGRAPHY}

Adams, P. E., \& Krockover, G. H. (1997). Beginning science teacher cognition and its origins in the preservice science teacher program. Journal of Research in Science Teaching, 34(6), 633-653.

Ashton, P., \& Crocker, L. (1987). Systematic study of planned variations: The essential focus of teacher education reform. Journal of Teacher Education, $38(3), 2-8$.

Barnes, C. J. (2006). Preparing preservice teachers to teach in a culturally responsive way. Negro Educational Review, 57(1/2), 85-100.

Boe, E. E., Shin, S., \& Cook, L. H. (2007). Does teacher preparation matter for beginning teachers in either special or general education? The Journal of Special Education, 41(3), 158-170. https://doi.org/10.1177/00224669070410030201.

Boyd, D. J., Grossman, P., Lankford, H., Loeb, S. \& Wyckoff, J. (2009). Teacher preparation and student achievement. Education Evaluation and Policy Analysis, 31(4)416-440.

Byrnes, D., Kiger, G., \& Shechtman, Z. (2003). Evaluating the use of group interviews to select students into teacher-education programs. Journal of Teacher Education, 54(2), 163-172.

Casey, C., \& Childs, R. (2011). Teacher education admission criteria as measure of preparedness for teaching. Canadian Journal of Education, 34(2), 3-20.

Clotfelter, C.T., Ladd, H.F., \& Vigdor, J.L. (2010). Teacher credentials and student 
achievement in high-school: A cross subject analysis with student fixed effects. Journal of Human Resources, 45(3), 655-681.

D’Agostino, J., \& Powers, S. (2009). Predicting teacher performance with test scores and grade point average: a meta-analysis. American Educational Research Journal, 46(1), 146-82.

Darling-Hammond, L. (2010, October 19). Evaluating Teacher Effectiveness. Retrieved from https://www.americanprogress.org/issues/education/reports/2010/10/19/8502/e valuating-teacher-effectiveness/

Darling-Hammond, L. (2006) Powerful Teacher Education: Lessons from Exemplary Programs. San Francisco: John Wiley and Sons, Inc. 21.

Darling-Hammond, L., Chung, R., \& Frelow, F. (2002). Variation on teacher preparation: How well do different pathways prepare teachers to teach? Journal of Teacher Education, 53(4), 286-302.

Darling-Hammond, L. (1991). Are our teachers ready to teach? Newsletter of the National Council for Accreditation of Teacher Education, 1, 6-7 \& 10.

DiObilda, N., Bolay, B., \& Foster, B. (1990). Selecting a process for evaluating teacher education programs. Education, 111(1), 43-52.

Educational Testing Service. 2017. Preparation Materials English Language Arts: Content and Analysis (5039). Retrieved March 19, 2017, from https://www.ets.org/praxis/prepare/materials/5039.

Education Testing Service. 2017. Preparation Materials Principles of Learning and Teaching (PLT): Grades 7-12 (5624). Retrieved March 19, 2017 
from https://www.ets.org/praxis/prepare/materials/5624.

Educational Testing Services (ETS). (2015). Understanding your Praxis scores 201516. Measuring the Power of Learning, 1-8. Retrieved from https://www.ets.org/s/praxis/pdf/uyps_1516.pdf

Evertson, C.M., Hawley, W.D., \& Zlotnik, M. (1985). Making a difference in educational quality through teacher education. Journal of Teacher Education, $36(3), 2-10$.

Ferguson, P., \& Womack, S.T. (1993). The impact of subject matter and education coursework on teaching performance. Journal of Teacher Education, 44(1), $55-63$.

Flowers, C. (2006). Confirmatory factor analysis of scores on the clinical experience rubric: A measure of dispositions of pre-service teachers. Educational and Psychological Measurement, 66(3), 478-488).

Goldhaber, D. (2007). Everyone's doing it, but what does teacher testing tell us about teacher effectiveness?. Journal of human Resources, 42(4), 765-794.

Grossman, P. L., \& Richert, A. E. (1988). Unacknowledged knowledge growth: A reexamination of the effects of teacher education. Teaching and Teacher Education, 4(1), 53-62.

Guyton, E., \& Farokhi, E. (1987). Relationships among academic performance, basic skills, subject matter knowledge, and teaching skills of teacher education graduates. Journal of Teacher Education, 38(5), 37-42.

Hall, P. C., \& West, J. H. (2011). Potential predictors of student teaching performance: Considering emotional intelligence. Issues in Educational Research, 21(2), 
145-161.

Hayes, M.T. (2002). Assessment of a field-based teacher education program: Implications for practice. Education, 122(4), 700-705.

Henry, G. T., Campbell, S. L., Thompson, C. L., Patricia, L. A., Luterbach, K. J., Lys, D. B., \& Covington, V. M. (2013). The Predictive Validity of Measures of Teacher Candidate Programs and Performance: Toward an Evidence-Based Approach to Teacher Preparation. Journal of Teacher Education, 64(5), 439453.

Ingersoll, R., Merril,L., and May, H. (2012). Retaining teachers: How preparation matters. Educational Leadership, 69(8), 30-34.

Jamil, F. M., Sabol, T. J., Hamre, B.K., \& Pianta, R.C. (2015). Assessing teachers' skills in detecting and identifying effective interactions in the classroom. Elementary School Journal, 115(3), 407-432.

Kornfeld, J., Marker, P.M., \& Rudel, M.R. (2003). Through the looking-glass: Selfstudy in an era of accountability. Teacher Education Quarterly, 30(3), 7-22.

Leathwood, C., \& Phillips, D. (2000). Developing curriculum evaluation research in higher education: Process, politics and practicalities. Higher Education, 40(3), 313-330.

Lee, J. (2002). Racial and ethnic achievement gap trends: Reversing the progress toward equity? Educational Researcher, 31(1), 3-12.

Morin, J. A. (1996). A research study designed to improve the preparation of social studies teachers. Education, 117(2), 241-251.

Moser, K. (2014). From Praxis to program development. Foreign Language Annals, 
47(1), 134-146.

National Council for Accreditation of Teacher Education. (2008). Professional standards for the accreditation of teacher preparation institutions. Washington, DC: Author.

Petchauer, E. P. (2012). Teacher licensure exams and Black teacher candidates: Toward new theory and promising practice. Journal of Negro Education, 81(3), 252-267.

Pettus, A. M., \& Smith, W. D. (1991). Program assessment for a teacher education program. Education, 112(2), 288-294.

Rhode Island Department of Education (RIDE). (2013). Rhode Island Standards for Educator Preparation. Retrieved from http://www.ride.ri.gov/Portals/0/Uploads/Documents/Teachers-and$\underline{\text { Administrators-Excellent-Educators/Educator-Certification/Becoming-an- }}$ Educator/RIPA Standards 2013.pdf.

Riggs, L. (2013, August). Why do teachers quit? And why do they stay? The Atlantic. Retrieved from http://www.theatlantic.com/education/archive/2013/10/whydo-teachers-quit/280699. Accessed Oct. 5, 2016.

Sandholtz, J. H., \& Shea, L. M. (2015). Examining the extremes: High and low performance on a teaching performance assessment for licensure. Teacher Education Quarterly, 42(2), 17-42.

Scheerens, J. J., \& Blömeke, S. S. (2016). Integrating teacher education effectiveness research into educational effectiveness models. Educational Research Review, 18(1), 70-87. 
Shulman, L.S. (1986). Those who understand: Knowledge growth in teaching. Educational Researcher, 15(2), 4-14.

Shulman, L.S. (1987). Assessment for teaching. An initiative for the profession. Phi Delta Kappan, 69(1), 38-44.

Thomas, A. M., \& Loadman, W. E. (2001). Evaluating teacher education programs using a national survey. Journal of Educational Research, 94(4), 195-206.

Warren, P. B., \& Curley, R. G. (1998). Evaluation, accountability and audience: how demands for accountability undercut program development. Education, 118(4), 492-498.

Watras, J. (2006). Teacher tests, equal opportunity, and the foundations of education. Educational Studies, 39(2), 124-134.

Williams, H. S., \& Alewife, O. (2001). Student teachers perceptions of a teacher training program. College Student Journal, 35(1), 113-118.

Wilson, B., \& Robinson, V. (2012). Potential teaching performance: Considering emotional intelligence. Journal of Assessment and Accountability in Educator Preparation, 2(1), 58-61.

Wilson, S. M., Floden, R. E., \& Ferrini-Mundy, J. (2001, February). Teacher preparation research: Current knowledge, gaps, and recommendations (Rep. No. R-01-3). Retrieved from http://www.education.uw.edu/ctp/teaching-andpolicy.

Wise, A. (2005). Testing does not equal teaching: One test does not make a highly qualified teacher. NCATE News. Retrieved from http://ncate.org/LinkClick.aspx?fileticket=tV4SVW9kjn8\%3D\&tabid=374 
Zhang, G., \& Zeller, N. (2016). A longitudinal investigation of the relationship between teacher preparation and teacher retention. Teacher Education Quarterly, 43(2), 73-92.

Zumwalt, K., Craig, E. (2005). Teacher's characteristics: Research on the indicators of quality. In M. Cochran-Smith \& K. Zeichner (Eds.), Studying Teacher Education: The report of the AERA panel on research and teacher education (pp.157-260). Mahwah, NJ: Lawrence Erlbaum Associates, Publish 